
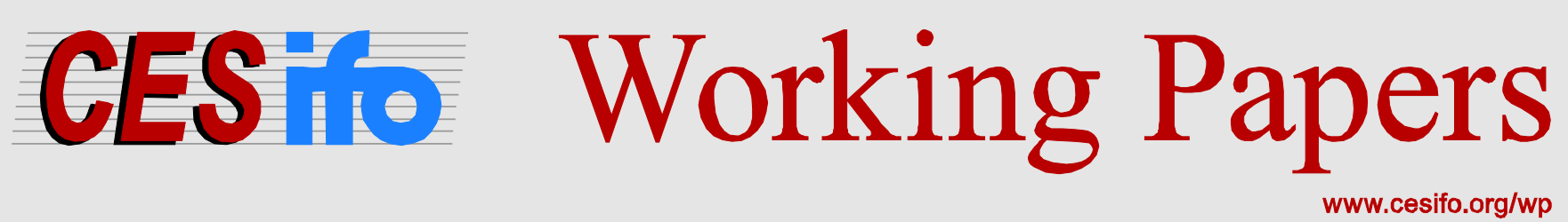

\title{
At Your Service! The Role of Tax Havens in International Trade with Services
}

\author{
Shafik Hebous \\ Niels Johannesen
}

CESIFO WORKING PAPER NO. 5414

CATEgORY 8: TRADE POLICY

JUNE 2015

An electronic version of the paper may be downloaded

- from the SSRN website:

- from the RePEc website:

- from the CESifo website:

wWw.SSRN.com

Www.RePEc.org

www.CESifo-group.org/wp 


\title{
At Your Service! The Role of Tax Havens in International Trade with Services
}

\begin{abstract}
This paper documents that tax havens play a prominent role in international service trade and investigates the nature of this role. We employ a firm-level dataset with detailed information about service trade and foreign affiliates for virtually all multinational firms in Germany, which allows us to approximately distinguish trade between related and unrelated parties. We find that the service trade of tax havens partly reflects genuine specialization in service industries, which suggests that institutional features such as low tax rates, secrecy and low regulatory standards create a comparative advantage in service production. We also find that trade in service categories such as intellectual property (patents and trademarks) and headquarter services (administration, management and advertising) partly reflects mispriced affiliate trade serving to shift profits to tax havens. We argue, however, that the loss of government revenue resulting from this type of corporate tax evasion is likely to be modest.
\end{abstract}

JEL-Code: F140, F230, H260.

Keywords: service trade, profit shifting, tax evasion, multinational firms, tax havens.

Shafik Hebous

Faculty of Economics and Business

Administration / Chair of Public Finance

Goethe University Frankfurt

Grüneburgplatz 1

Germany - 60323 Frankfurt am Main

hebous@wiwi.uni-frankfurt.de
Niels Johannesen

Department of Economics

University of Copenhagen

Øster Farimagsgade 5, building 26

Denmark - 1353 Copenhagen

niels.johannesen@econ.ku.dk

June 24, 2015

We thank the staff of the Research Data and Service Centre (RDSC) at the Deutsche Bundesbank, particularly Simone Schultz, Christopher-Johannes Schild and Rafael Beier, for their kind support. We are grateful for comments from conference participants at the University of Tübingen as well as from Joel Slemrod. Niels Johannesen gratefully acknowledges generous financial support from the Danish Council for Independent research. 


\section{Introduction}

One of the most remarkable features of the globalization wave in recent decades is the explosive growth in international trade with services. Service trade has consistently grown at higher rates than goods trade and, today, commercial services account for roughly $20 \%$ of the total international trade (WTO, 2013).

This paper argues that the rise in international service trade cannot be fully understood without accounting for the role of tax havens: jurisdictions with extremely low effective tax rates often combined with low regulatory standards and legal institutions facilitating secrecy. We substantiate this claim by showing that in all the OECD countries, for which a bilateral breakdown of service trade flows is available, the share of trade that is conducted with tax havens is substantially higher for services than for goods. Simple gravity models of aggregate trade flows show that service trade with tax havens is around 6 times larger than with comparable countries that are not tax havens whereas no such difference exists in goods trade.

A priori there are at least two plausible explanations for the striking role of tax havens in international service trade. First, the specific institutions developed by tax havens may create a comparative advantage in services. For instance, bank secrecy and tax exemption of investment funds have spurred the development of a large financial sector in Luxembourg, which trades a wide range of services on the global financial market. Ship management on Cyprus and reinsurance on Bermuda are other examples of genuine and highly specialized service industries that have emerged in response to the tax and regulatory incentives offered by tax havens. Second, service trade may serve as a tax evasion strategy for multinational firms. When tax haven entities sell overpriced services to affiliated entities elsewhere, taxable profits are effectively shifted to tax havens with low or no taxation, which reduces the firm's global tax bill. Anecdotally, multinational firms are known to operate tax haven entities such as "patent boxes" that own intellectual property and collect royalties and license fees from affiliates; "captive insurance companies" that insure the risks of affiliates in exchange for insurance fees; and "headquarters" that assist affiliates with management, administration or advertising against service fees. These transactions are all classified as service trade in international trade statistics, but typically have no or little real substance and serve no other purpose than tax evasion.

The rest of the paper explores the nature of the service trade with tax havens: does it reflect real agglomerations of service industries in tax havens or tax evasion by multinational firms? 
Our empirical strategy involves two steps. First, we break down the "excess" service trade with tax havens into trade between unrelated parties, which must reflect genuine specialization in service industries, and trade between related parties, which may reflect tax-motivated profit shifting. Second, we study whether tax haven entities selling services to affiliates exhibit "excess" profitability, which would indicate that these transactions involve an element of profit shifting.

To conduct this analysis, it is necessary to go beyond aggregate trade statistics. Therefore, we combine two German data sources to construct a firm-level dataset that contains information about service trade as well as foreign direct investment. For each German firm, we observe the value of its service imports and exports by foreign counterpart country and service category as well as the location and basic characteristics of its foreign affiliates.

Our baseline regression model explains the extensive margins of service trade with the following three key variables: a dummy indicating whether the partner country in question is a tax haven; a dummy indicating whether the firm in question has an affiliate in the partner country; and the interaction between the tax haven and affiliate dummies. In addition, we include standard gravity controls as well as firm fixed effects that absorb all firm-level determinants of trade such as firm age, size and sector. The tax haven dummy measures the probability of a German firm trading with a haven in which it has no affiliates over and above the probability of trading with an otherwise similar non-tax haven in which it has no affiliates; a measure of excess trade with unrelated parties in tax havens. The interaction between the tax haven and subsidiary dummies measures the probability of a German firm trading with a tax haven in which it has an affiliate over and above the probability of trading with an otherwise similar non-tax haven in which it has an affiliate; a measure of excess trade with affiliates in tax havens.

We find strong evidence of excess trade with unrelated parties in tax havens across virtually all service categories. The excess probability that a given firm imports from a given tax haven where it has no affiliates is between 0.1 and 1 percentage point depending on the service category. Precisely because this finding applies to trade between unrelated parties, it implies that tax havens sell more genuine services on the world market than can be explained by their fundamental economic and geographical characteristics, which we interpret as evidence of specialization in services. The excess probability that a firm exports to a tax haven where it has no affiliates is between 0.1 and 0.4 percentage points. This finding plausibly reflects that service agglomerations in tax havens rely on service inputs from foreign providers; for instance, Luxembourg banks may acquire financial services on the world market just like Cypriot ship- 
ping companies buy shipping-related services and Bermuda reinsurance companies purchase insurance-related services from unrelated firms abroad.

Moreover, for certain service categories often anecdotally associated with tax evasion, we find positive excess imports from affiliates in tax havens, but negative excess exports. For example, if a firm has an affiliate in a foreign country, the probability of observing trade flows related to intellectual property between the firm and the foreign country generally increases by around 5 percentage points for both imports and exports. However, if the foreign country is a tax haven, the effect on imports is around 7.5 percentage points and the effect on exports only around 2.5 percentage points. We find evidence of positive excess imports from affiliates in tax havens combined with negative excess exports in four major service categories: intellectual property (such as services related to patents and trademarks), headquarter services (such as administration and management), information services and sea transport. The first two categories are often considered to be especially prone to transfer mispricing because of the difficulty of establishing market prices for such services (e.g. OECD, 2013) while the latter is closely linked to tax havens by the extensive use of flags of convenience.

The finding that affiliate trade with tax havens is heavily skewed towards imports is clearly consistent with profit shifting. It is precisely the pattern that should be expected if multinational firms operate tax haven entities serving solely to sell mispriced or even purely fictitious services to affiliates. However, the finding could also, in principle, reflect that multinational firms allocate a disproportionate share of their genuine service production to affiliates in tax havens while trading services internally at market prices. We therefore go beyond the analysis of trade patterns and study the profitability of foreign affiliates directly.

Our methodology effectively compares entities belonging to the same firm and selling the same service to their German affiliates. We find that for certain service categories, notably intellectual property, headquarter services and sea transport where affiliate trade with tax havens is significantly skewed toward imports, tax haven affiliates earn significantly higher profits than non-haven affiliates. The excess return of tax haven affiliates is between 4 and 8 percentage points depending on the service category, which compares to normal returns between 10 and 15 percent in the comparison group of non-haven affiliates. Relatedly, we show that patterns in service trade correlate strongly with the intra-firm allocation of profits. Specifically, firms with less than $20 \%$ of total service imports coming from tax havens typically allocate below $30 \%$ of their foreign profits to tax havens whereas firms importing $50 \%$ or more from tax havens allocate around $50 \%$ of their foreign profits to tax havens. These results suggest that some 
affiliate trade is mispriced and has an economically significant effect on the global allocation of profits within multinational firms.

Finally, we present suggestive evidence that service trade between German firms and their tax haven affiliates is funneled through entities in third countries; in particular the Netherlands, which has been identified by other studies as the conduit country typically used by German firms for holding purposes (e.g. Mintz and Weichenrieder, 2010). Specifically, we show that excess probabilities of imports from tax haven affiliates in service categories such as intellectual property and headquarter services are significantly lower for German firms that have an affiliate in the Netherlands. This is consistent with services flowing from tax havens through the Netherlands to Germany, which decreases observed imports from tax haven affiliates, but only for firms that have an affiliate in the Netherlands. The conduit trade may serve to circumvent withholding taxes or other anti-avoidance measures that apply only to transactions with tax havens (Johannesen, 2012).

The paper adds to a large literature studying how multinational firms shift profits between jurisdictions with the aim of reducing their global tax bill. A number of papers show that the transformation of productive inputs into taxable profits by multinational firms correlates with tax rates in ways that are suggestive of tax motivated profit shifting (e.g. Hines and Rice, 1994; Huizinga and Laeven, 2008). Other papers study the distinct channels through which profits are shifted such as mispricing of goods traded inside the firm (e.g. Clausing, 2003; Bernard, Jensen and Schott, 2008; Christea and Nguyen, 2015); the allocation of debt within the firm (e.g. Desai, Foley and Hines, 2004; Huizinga, Laeven and Nicodeme, 2008); and the allocation of patents and other intangible assets within the firm (e.g. Dieschinger and Riedel, 2011; Karkinsky and Riedel, 2012) as well as the resulting flows of royalties (e.g. Grubert, 1998). We are not aware of any existing papers studying trade in services as a mode of profit shifting.

Moreover, the paper contributes to a broader empirical literature that investigates the trade boom in services in terms of its causes, for instance Jensen (2011) on enhanced tradability of services and Francois and Hoekman (2010) on reduced non-tariff barriers to trade; its consequences, for instance Haskel et al. (2012) on increased income inequality, Trefler and Liu (2008) on depressed earnings of domestic workers and Arnold, Javorcik, Mattoo (2011) on increased productivity of downstream manufacturing firms; as well as its anatomy, for instance Breinlich and Criscuolo (2011) on the heterogeneity across service firms in the propensity to trade and Kelle et al. (2013) on the relative importance of direct service exports and service sales through foreign affiliates. To the best of our knowledge, no existing papers link the rise of international 
service trade to tax and regulatory arbitrage.

Finally, our findings relate to a growing body of literature attempting to shed light on the use of tax havens by multinational firms (Hines and Rice, 1994; Desai et al., 2006; Hebous and Lipatov, 2014; Zucman, 2014; Bennedsen and Zeume, 2015); wealthy individuals (Zucman, 2013; Zucman and Johannesen, 2014; Johannesen, 2014; Hanlon et al., 2014); and political elites in autocracies (Andersen et al., 2014).

The paper proceeds in the following way. Section 2 presents evidence on the role of tax havens in international trade based on aggregate trade flows. Section 3 describes the German firm-level data on service trade and foreign investment. Section 4 discusses the empirical strategy. Section 5 reports the results. Section 6 provides some concluding remarks.

\section{Aggregate trade patterns}

This section analyzes the role of tax havens in international trade using publicly available data from OECD trade statistics. Specifically, we rely on bilateral trade information from 2011, which is available for 34 countries for goods and 26 countries for services.

In a first step, we show that tax havens play a far more prominent role in service trade than goods trade by plotting the share of service trade that is conducted with tax havens against the corresponding share in goods trade. Our list of tax havens follows Hines (2010) and includes 50 countries ranging from well-known tax havens like Switzerland, Singapore and Bermuda to more unknown jurisdictions like Anguilla, Andorra and Vanuatu. As shown in Figure 1, tax havens are more important partners in service trade than goods trade for all countries in the sample. In Germany and France, for instance, tax havens account for around $15 \%$ of the service trade but only a little more than $5 \%$ of goods trade; in the UK, tax havens account for almost $20 \%$ of the service trade and roughly $10 \%$ of the goods trade; and, most extremely, in the Netherlands, tax havens account for almost $25 \%$ of the service trade and a mere $5 \%$ of the goods trade.

Figure 1 somewhere around here

In a second step, we quantify the extent to which trade with tax havens exceeds trade with comparable non-haven countries by estimating a standard gravity model augmented with tax variables. The results are reported in Table 1; all standard errors are clustered by reporting country and by partner country. Column (1) shows that conditional on economic size, geography and other standard controls, a dummy for being a tax haven is a very strong predictor of service trade. The coefficient of 1.79 implies that service trade is around $500 \%$ percent larger for country 
pairs where at least one of the countries is a tax haven than for otherwise comparable country pairs. Column (2) shows that this result does not extend to goods trade. The point estimate suggests tax havens trade around $16 \%$ more goods than comparable non-havens, which is not statistically distinguishable from zero.

Table 1 somewhere around here

These patterns are very robust. For instance, the coefficient on the tax haven dummy barely changes when we include higher-order terms of the GDP and distance variables to address the concern that tax havens are systematically smaller than other countries, which could lead to a biased coefficient on the tax haven dummy if trade is not log-linear in GDP conditional on any tax effects. The point estimate drops somewhat when the gravity equation is estimated on its multiplicative form as suggested by Silva and Tenreyro (2006), but still implies excess trade with tax havens in services above $200 \%$. By comparison, point estimates are consistently small and statistically insignificant in the goods equation.

In the baseline regression, we lumped together country pairs where only one country is a tax haven and those where both countries are tax havens in a single tax haven dummy. Column (3) shows that the service trade effect is markedly different in the two cases: the coefficient of 1.67 for country pairs with only one tax haven corresponds to a trade effect of around $430 \%$ whereas the coefficient of 4.21 for country pairs with two tax havens corresponds to a trade effect of a staggering $6600 \%$. Column (4) shows that there is no significant effect on goods trade in any of the two cases.

The very sizable trade in services between tax havens strongly suggests that simple profit shifting from high-tax to low-tax countries cannot fully account for the important role of tax havens in international service trade. A possible explanation, which we will investigate further later in the paper, is that services are traded through chains of entities belonging to the same firm. In the tax planning employed by Microsoft, Google and other global firms, for instance, the right to exploit the firm's intellectual property is licensed from a shell corporation in Bermuda to another shell corporation in the Netherlands, on to a corporation in Ireland and finally on to sales offices in a number of different countries (Kleinbard, 2011). ${ }^{1}$ Such structures generate service trade flows between tax havens that can be very large relative to the size of the tax

\footnotetext{
${ }^{1}$ The role of chains of entities is studied empirically by Mintz and Weichenrieder (2010) and Lewellen and Robinson (2013).
} 
haven economies.

While the aggregate trade statistics point to a prominent role of tax havens in international service trade, they do not allow us to investigate this role further by considering trade between related and unrelated entities separately or analyzing individual service categories. In the remainder of the paper, we therefore turn to more disaggregated data.

\section{Firm-level data}

We combine information from two firm-level datasets compiled by the Deutsche Bundesbank. First, we use information on service trade from the Statistics on international trade in services collected for the purposes of the balance of payments statistics. In this dataset, we observe for each German corporation the value of its service imports and exports by counterpart country and service category. ${ }^{2}$ Second, we use information on foreign affiliates from the Microdatabase Direct Investment (MIDI). In this dataset, we observe for each German corporation the basic characteristics of its foreign affiliates, such as their turnover, profits, equity and location, both directly and indirectly owned subsidiaries and parent companies. ${ }^{3}$ Merging these two data sources, we obtain a firm-level dataset on service trade and foreign affiliates, which is augmented with country-level variables such as GDP, tax haven status, distance to Germany and shared language with Germany ${ }^{4}$.

It should be emphasized that the data do not allow us to distinguish trade between related and unrelated entities without error. First, when a firm trades with a country in which we observe an affiliate, this could very well be trade with the affiliate, but might also be trade with another unrelated entity. Second, trade with a country in which we do not observe an affiliate is most likely trade with an unrelated entity, but could in principle be trade with an affiliate that we do not observe in our dataset. That could happen if the trading partner is a subsidiary of a foreign parent (i.e., a foreign sister) for which there is no reporting requirement to the Deutsche Bundesbank.

In Table 2, we provide an overview of the aggregate patterns in our firm-level dataset. For each of the 11 broad service categories with aggregate trade exceeding $€ 5$ billion, we report

\footnotetext{
${ }^{2}$ The data cover all transactions exceeding $€ 12,500$

${ }^{3}$ Foreign subsidiaries are included if (i) the value of their total assets exceeds $€ 3$ million and (ii) the German parent holds a direct ownership share exceeding $10 \%$ or one of its subsidiaries holds a direct ownership share exceeding 50\%. For a detailed description of the data, see Biewen et al. (2013) and Lipponer (2011).

${ }^{4}$ Information on GDP from World Development Indicators complemented with CIA factbook; on tax haven status from Hines (2010); and on geography, shared language and shared borders from the CEPII database.
} 
the total value of German firms' imports and exports with breakdowns on whether the partner country is a tax haven or not and whether a foreign affiliate is present in the partner country or not. The table establishes a number of interesting facts. First, Germany has a considerable trade deficit in services with imports around $€ 250$ billion and exports around $€ 220$ billion. The largest service categories in terms of total trade are Sea transport, Intellectual property, Air transport and, most importantly, Other business services. Second, Germany has a small trade surplus against tax havens with exports around $€ 40$ billion and imports slightly below that. The share of tax havens in the service trade, however, varies widely across categories with particularly high tax haven shares in Financial services, Sea transport, Information services and Other business services (20-30\%) and low tax haven shares in Air transport and Road transport (5-7\%). Third, trade with tax havens in which the trading firm has an affiliate and which is therefore plausibly intra-firm amounts to around $€ 11$ billion of imports and $€ 8$ of exports. The intra-firm share of tax haven imports also differs significantly across services with high intra-firm shares in Intellectual property and Other business services (30-50\%) and a low share in Financial services and Construction (15-20\%).

In Table 3, we report a breakdown of the two aggregate categories Intellectual property and Other business services, which are of particular interest in the context of profit shifting. The former can be decomposed into Patents, Trademarks and Research and Development whereas the latter most prominently contains Headquarter services, Technical services and Advertising as well as a number of smaller subcategories. The term Headquarter services is used for brevity and covers commercial, organizational, administrative and management services.

The aggregate patterns reported in Tables 2 and 3 can be used to gauge the magnitude of profit shifting to tax havens occurring through trade in services. Under the extreme assumption that all service imports from tax havens in which the importing firm has an affiliate are purely fictitious transactions where the acquired service has no actual value, these imports shift $€ 11$ billion of corporate tax base out of Germany. With a corporate tax rate around $30 \%$, this gives an upper bound on the revenue loss due to intra-firm service imports from tax havens of around $€ 3$ billion. To the extent that some of these imports represent genuine services with a positive market value, the revenue loss is proportionately smaller. This computation does not account for the possibility that imports from tax havens are funneled through conduit countries and thus concealed as imports from other countries. Note, however, that even if a large share of affiliate imports from tax havens is completely fictitious and a significant share of total affiliate imports from tax havens pass through conduit entities outside tax havens, the total revenue 
loss is likely to be quite modest relative to the total German corporate tax revenue of around $€ 45$ billion in $2011 .^{5}$

\section{Empirical model}

The baseline model used to study trade patterns is a linear probability model specified in the following way:

$$
\text { Trade }_{i c s}=\alpha+\beta_{1} \text { Haven }_{c}+\beta_{2} \text { Affiliate }_{i c}+\beta_{3}\left(\text { Affiliate }_{i c} \times \text { Haven }_{c}\right)+\mu_{i}+\gamma \mathbf{X}_{c}+\varepsilon_{i c s}
$$

where Trade $_{i c s}$ is a measure of trade in service $s$ between firm $i$ and country $c$; Affiliate Af $_{i c}$ is dummy indicating whether firm $i$ has an affiliate in country $c$; Haven He a dummy indicating whether country $c$ is a tax haven; $\mu_{i}$ are firm-level fixed effects that absorb all firm characteristics such as size, sector and overall propensity to engage in cross-border transactions; and $\mathbf{X}_{c}$ is a vector of country-level gravity controls such as GDP and distance to Germany. We study the two external margins of trade by varying the dependent variable: Import $_{i c s}$ is a dummy indicating whether firm $i$ imports service $s$ from country $c$ and Export $t_{i c s}$ is a dummy variable indicating whether firm $i$ exports service $s$ to country $c$. The model is estimated for each of the two trade measures and for each service category separately.

We interpret the coefficients on the three key variables in the following way: First, the coefficient on Tax Haven measures the average trade of a German firm with a tax haven in which it has no affiliates over and above its trade with an otherwise similar non-tax haven in which it has no affiliates. This is a measure of excess trade with unrelated parties in tax havens. Second, the coefficient on Af filiate measures the average trade of a German firm with a non-tax haven in which it has an affiliate over and above its trade with an otherwise similar non-tax haven in which it has no affiliates. It is natural to interpret this as a measure of affiliate trade, but caution is warranted because the presence of a foreign affiliate could also affect trade with unrelated parties. For instance, a foreign affiliate could promote transactions between its German parent and unrelated parties, in which case $\beta_{2}$ overestimates affiliate trade, or replace the German parent in transactions with unrelated parties, in which case it underestimates affiliate trade. Finally, the coefficient on the interaction between Tax Haven and Affiliate measures the average trade of a German firm with a tax haven in which it has an affiliate

\footnotetext{
${ }^{5}$ Dhamarpala (2014) surveys the empirical literature on profit shifting and concludes that recent studies employing rich firm-level data tend to find less profit shifting than earlier studies.
} 
over and above its trade with an otherwise similar non-tax haven in which it has an affiliate. This is a measure of excess trade with affiliates in tax havens. Note that even if $\beta_{2}$ does not correctly identify affiliate trade because of the confounding effect of affiliates on trade with related parties, $\beta_{1}$ and $\beta_{3}$ correctly identify excess trade provided that this effect is the same in tax havens and other countries.

It should be noted that the presence of firm fixed effects in the model implies that the variables of interest are identified exclusively from within-firm comparisons. Effectively, we are comparing a firm's trade with tax havens to the same firm's trade with non-tax havens and a firm's trade with countries in which it has an affiliate to the same firm's trade with countries in which it has no affiliates while holding constant country characteristics such as GDP and distance to Germany.

The model allows us to test the following hypotheses. If multinational firms operate tax haven entities that serve to sell mispriced or fictitious services to other affiliates, we should expect: a higher probability of observing imports from affiliates in tax havens than from affiliates in comparable countries ( $\beta_{3}>0$ in the imports equation) and a lower probability of observing exports ( $\beta_{3}<0$ in the exports equation). Moreover, if tax havens specialize in the production of real services, we should expect: a higher probability of observing imports from unrelated parties in tax havens than from unrelated parties in comparable countries $\left(\beta_{1}>0\right.$ in the imports equation). The probability of observing exports to unrelated parties in tax havens could be lower than for other countries if local service sectors in tax havens tend to saturate their own domestic market ( $\beta_{1}<0$ in the export equation) or higher than for other countries if local service sectors in tax havens tend to rely on intra-industry inputs from foreign firms $\left(\beta_{1}>0\right.$ in the export equation). To be concrete, the large financial sector in Luxembourg may cause purchases of financial services from abroad to be smaller than in comparable countries because domestic firms have ample access to financial services locally, or larger because the domestic financial sector relies relatively strongly on financial service inputs, some of which are purchased abroad.

Moreover, we specify the following model to estimate the excess profitability of tax haven entities selling services to affiliates:

$$
\text { Profitability }_{i c s}=\alpha+b_{1} \text { Haven }_{c}+\mu_{i}+\varepsilon_{i c s}
$$

where Profitability Pics $_{\text {is }}$ the book return on equity of an affiliate belonging to firm $i$ located in country $c$ from which the firm imports service $s$; Haven $_{c}$ is a dummy indicating whether country $c$ is a tax haven; and $\mu_{i}$ are firm-level fixed effects. The book return is winsorized conservatively 
at the $5 \%$ and $95 \%$ level. The model is estimated for each service category separately.

In each regression, the sample includes all foreign affiliates located in a country from which the German affiliate imports a given service. The fixed effects absorb firm-level differences in profitability, so we are effectively identifying the excess profitability of tax haven entities selling services to their German affiliates by comparing to entities in other countries belonging to the same firm selling the same service to their German affiliates.

\section{Results}

\subsection{Trade}

In the first set of regressions, we estimate equation (1) for each of the 11 broad service categories and each of the two trade variables. Firms are included in the sample if they trade the specific service category being studied from at least one foreign country, which implies that the sample size differs somewhat across service categories. All regressions use a cross-section for the year 2011. Standard errors are clustered at the firm-level unless reported otherwise.

Table 4 reports the regression results with Imports as dependent variable. There are three sets of findings. First, for all service categories there is a positive coefficient on Haven suggesting excess imports from unrelated parties in tax havens. The point estimates range from 0.1 percentage points to more than 1 percentage point depending on the specific service category. To provide a sense of these magnitudes, we report the unconditional probability of trade with unrelated parties in non-havens at the bottom of the table. The comparison suggests that for most services, the excess probability of imports from unrelated parties in an average tax haven is of roughly the same magnitude as the baseline probability of imports from unrelated parties in an average non-haven.

Second, for all service categories except Sea transport, there are positive coefficients on Affiliate, which provide rough measures of affiliate trade (recall the caveat discussed in the previous section). The point estimates suggest, for instance, that German firms import Air transport services from less than 1 percent and Other business services from around 20 percent of its foreign affiliates outside tax havens.

Third, for the service categories Information services, Intellectual property, Other business services, Financial services and Sea transport, there is a positive coefficient on the interaction between Haven and Affiliate suggesting excess imports from affiliates in tax havens. The significant point estimates range from just below 1 percentage point to almost 3 percentage 
points. Comparing the coefficients on Haven $\times$ Affiliate to those on Affiliate suggests that excess affiliate imports range from $10 \%$ of normal affiliate imports, in Other business services, to more than $60 \%$, in Financial services. In the remaining categories the coefficient on the interaction term is indistinguishable from zero, except for Construction where the coefficient is significantly negative. The coefficients on the covariates are as expected: imports are more likely when the foreign country is closer, larger and shares a border or an official language with Germany.

Table 4 somewhere around here

In Table 5, we report the results obtained from estimating equation (1) with Exports as the dependent variable. The generally positive coefficients on Haven suggest that there are excess exports to unrelated parties in tax havens. The significant point estimates range from less than 0.1 percentage points to 0.4 percentage points and are smaller than in the imports regressions except in the case of Financial services. The generally positive coefficients on Affiliate are suggestive of exports by German firms to affiliates outside tax havens. For all service categories except Communication, Insurance services and Financial services, there is a negative coefficient on the interaction between Haven and Affiliate suggesting that there are negative excess exports to affiliates in tax havens. The coefficients on the covariates suggest that exports, just like imports, are more likely when the foreign country is closer, larger and shares a border or an official language with Germany.

Table 5 somewhere around here

In the remainder of the paper, we focus on the extensive import margin due to space constraints and the fact that imports from tax havens provide clearer and more easily interpretable evidence on both specialization and profit shifting.

In Table 6, we split the sample of firms into 3 industrial sectors and provide regression results for each sector separately. Broadly, there is strong evidence of excess imports from unrelated parties in tax havens in all three sectors across almost all service categories. Interestingly, however, the excess imports from affiliates in tax havens is concentrated among manufacturing firms. Here, the interaction between Haven and Affiliate is positive in more than half of the service categories and the estimated coefficients are considerably larger than in the full sample, both in absolute terms and relative to the coefficient on Affiliate. The latter comparison implies that excess affiliate imports approaches or exceeds $100 \%$ of normal affiliate imports in 
each of the categories information services, communication services, intellectual property and sea transport. By contrast, there is little evidence of excess imports from affiliates in tax havens among service firms. The main exception to this broad pattern is financial services where excess imports from tax haven affiliates in the full sample appears to be driven primarily by service firms.

Table 6 somewhere around here

Finally, in Table 7, we provide regression results for the narrow service categories underlying the broader categories intellectual property and other business services. These categories are especially interesting in this context, firstly because we have found evidence of trade with tax haven affiliates being skewed toward imports throughout all the specifications and, secondly, because they are both among the broad service categories that contain the most aggregate trade. The consistently positive coefficients on Tax Haven are clear evidence of excess imports from unrelated parties in tax havens across all the narrow service categories. By contrast, the coefficients on the interaction term indicate that excess imports from affiliates in tax havens are concentrated in trade with patents and trademarks within intellectual property, and in trade with headquarter services and advertising within other business services.

Table 7 somewhere around here

\subsection{Profitability of foreign affiliates}

While the patterns of affiliate trade are consistent with profit shifting to tax havens through the sale of mispriced services, patterns of profitability across foreign affiliates can potentially provide more direct evidence on profit shifting. We therefore estimate equation (2) for each of the 11 broad service categories.

Table 8 shows that tax haven entities selling services to their German affiliates have significantly higher book returns than other entities belonging to the same firm and selling the same services to German affiliates in 5 of the service categories. The excess returns range from around 4 percentage points for Intellectual property to around 8 percentage points for Construction. By comparison, the mean return of non-tax haven entities selling services to German affiliates (reported at the bottom of the table) ranges from around 8 percent to around 15 percent.

Table 8 somewhere around here 
The finding that tax haven entities engaged in inter-affiliate service trade earn excess returns is highly suggestive that these transactions involve a significant element of profit shifting. The regressions, however, do not inform us about the effect of affiliate service trade on the global allocation of profits within the firm.

To shed light on this issue, Figure 2 displays a binned scatterplot of the ratio of tax haven service imports to total service imports against the ratio of tax haven profits to total foreign profits. Each blue dot represents the average ratio of tax haven profits to total foreign profits within a narrow range of ratios of tax haven service imports to total service imports. The figure documents a strong correlation between service trade and the allocation of profits with the firm. Specifically, firms with less than $20 \%$ of service imports coming from tax havens typically allocate below $30 \%$ of their foreign profits to tax havens whereas firms with $50 \%$ or more of service imports coming from tax havens allocate around $50 \%$ of their foreign profits to tax havens. These results are suggestive that affiliate trade in services is a quantitatively important channel through which firm profits are shifted to tax havens.

Figure 2 somewhere around here

\subsection{Conduit trade}

Our analysis may underestimate excess imports from affiliates in tax havens if services are funneled through conduit entities in third countries. Firms may use conduit structures to avoid withholding taxes on royalty payments applying to tax havens but not other countries or to make service charges look more legitimate by letting the provider be affiliates in respectable non-tax havens. Tax motivated conduit structures to eliminate withholding taxes on dividend payments have been analyzed empirically (Mintz and Weichenrieder, 2010) and discussed theoretically in the context of interest payments (Johannesen, 2012) and hybrid financial instruments (Johannesen, 2014).

The main challenge associated with the study of conduit structures in service trade is that while we observe trade flows between Germany and any partner country, we do not observe trade flows between other country pairs. Hence, we are constrained to base our inference on the correlation between trade flows in and out of Germany and the location of foreign affiliates of German firms. We focus on conduit trade flows through the Netherlands, which has anecdotally been linked to conduit flows related to intellectual property (Kleinbard, 2011) and which has been identified as the main conduit country used by German firms for holding purposes by 
existing academic studies (e.g. Mintz and Weichenrieder, 2010). Specifically, we re-estimate our baseline model while allowing excess imports from affiliates in tax havens to differ between firms that have an affiliate in the Netherlands and firms that do not. If firms funnel service imports from tax havens through affiliates in the Netherlands, we should expect these firms to have less excess imports directly from tax havens. We apply the model to each of the narrow service categories within Intellectual property and Other business services where we have consistently found evidence of mispriced trade.

Table 9 reports the results from the baseline specification where the coefficients of interest are interacted with $N L$ affiliate, which is a dummy variable indicating whether the firm has an entity in the Netherlands. The coefficient on the interaction between Haven and Affiliates measures excess imports from tax haven affiliates for firms that are not present in the Netherlands. The point estimates are qualitatively similar to the baseline estimates reported in Table 7, but the estimated effects are larger. The coefficient on the triple interaction between Haven, Affiliate and NL affiliate measures how excess imports from tax haven affiliates differs between firms that are and firms that are not present in the Netherlands. In seven service categories, including Patents and Trademarks within Intellectual property and Headquarter services and Advertising within Other business services, excess imports from tax haven affiliates are significantly smaller when firms have an affiliate in Netherlands. Interestingly, in most of these categories, excess imports from tax haven affiliates are close to zero for firms with a presence in the Netherlands. In none of the service categories are excess imports from tax haven affiliates larger for firms that are present in Netherlands than for those that are not.

Table 9 somewhere around here

\subsection{Robustness}

Table 10 reports two robustness tests of the model estimated above. First, we estimate the baseline specification for imports with a logit model. As shown in Panel A, the results are very similar to the baseline results estimated with a linear probability model (reported in Table 4). With the logit model, we find excess trade with unrelated parties in tax havens in all service categories except Construction. Moreover, we find excess trade with affiliates in tax havens in the service categories Information services, Intellectual property, Other business services, Insurance services and Financial services. The main differences are that excess trade with affiliates in tax havens becomes statistically significant for Insurance services in the logit model 
whereas it drops to bordeline statistical significance for Sea transport.

\section{Table 10 somewhere around here}

Second, we add country fixed effects to the baseline linear probability model to account for all country characteristics that affect patterns of service trade. In this specification, the tax haven dummy as well as the country covariates are unidentified, but we can still estimate the excess probability of trade with tax haven affiliates. As shown in Panel B, the results are again very similar to the baseline results. The main difference is that excess trade with affiliates in tax havens becomes statistically significant at the $1 \%$ level rather than at the $10 \%$ level for Communication services.

\section{Conclusion}

This paper has used aggregate trade data to show that tax havens play a prominent role in international trade with service trade and firm-level data to explore this role: does it reflect genuine specialization in services by tax havens or tax evasion by multinational firms? We showed that firm-level patterns in service trade and foreign investment are consistent with both genuine specialization and profit shifting and, further, that entity-level patterns in profitability support the notion that intra-firm service trade serves to shift profits to tax havens. Finally, we found evidence suggestive of conduit service trade with tax haven affiliates through affiliates in the Netherlands.

While the evidence suggests that service imports from tax haven affiliates play a role in tax evasion, we argued that the implications for government revenue are likely to be modest. Even under the extreme assumption that all service imports from tax haven affiliates are purely fictitious transactions where the acquired service has no actual value, the implied revenue loss would be around $€ 3$ billion or, equivalently, around $7 \%$ of the total German corporate tax revenue. Our regression results suggested that excess service imports from haven affiliates are rarely above $100 \%$ of normal imports and often much less than that. Taken at face value these results imply that not more than half of the service imports from tax havens are tax motivated and, hence, that the government revenue loss is considerably smaller than the upper bound of $€ 3$ billion.

The latter finding speaks to contemporary debates about the revenue consequences of international tax planning by global firms. Based on information about the international allocation of profits within U.S. firms, Zucman (2014) sets the annual revenue loss at a staggering $\$ 200$ 
billion for the U.S. government alone. Hines (2014) use existing estimates of the tax sensitivity of reported profits to arrive at an upper bound of the revenue loss of around $2-4 \%$ of the total corporate tax revenue, or around $\$ 10-20$ billion for the U.S. government. While our analysis only covers one dimension of profit shifting, service trade with tax havens, and therefore cannot hope to bring definitive answers to this debate, our finding that the revenue losses resulting from service trade with tax havens are modest do suggest that the consequences of corporate tax avoidance are perhaps less serious than implied by the most pessimistic estimates.

\section{References}

[1] Andersen, J., Johannesen, N., Lassen, D., Paltseva, E., 2014. Petro rents, political institutions, and hidden wealth: Evidence from offshore bank accounts. Unpublished working paper.

[2] Arnold, J., Javorcik, B., Mattoo, A., 2011. Does services liberalization benefit manufacturing firms? Evidence from the Czech Republic. Journal of International Economics 85, p. $136-146$.

[3] Bennedsen, M., Zeume, S., 2015. Corporate tax havens and shareholder value. Unpublished working paper.

[4] Bernard, A., Jensen, J., Schott, P., 2008. Transfer pricing by U.S.-based multinational firms. NBER Working Paper No. 12493

[5] Biewen, E., Blank, S., Lohner, S., 2013. Microdatabase: Statistics on international trade in services. Technical Documentation. Deutsche Bundesbank, February, Frankfurt.

[6] Breinlich, H., Criscuolo, C., 2011. International trade in services: A portrait of importers and exporters. Journal of International Economics 84, p. 188-206.

[7] Christea, A., Nguyen, D., 2015. Transfer pricing by multinational firms: New evidence from foreign firm ownerships. American Economic Journal: Economic Policy, forthcoming.

[8] Clausing, K., 2003. Tax-motivated transfer pricing and US intrafirm trade prices. Journal of Public Economics 87, p. 2207-2223

[9] Desai, M., Foley, F., Hines, J., 2004. A multinational perspective on capital structure choice and internal capital markets. Journal of Finance. 59(6), p. 2451-2487. 
[10] Desai, M., Foley, F., Hines, J., 2006. The demand for tax haven operations. Journal of Public Economics 90, p. 513-531

[11] Dieschinger, M., Riedel, N., 2011. Corporate taxes and the location of intangible assets within multinational firms. Journal of Public Economics 95, p. 691-707.

[12] Dhamarpala, D., 2014. What Do We Know about Base Erosion and Profit Shifting? A Review of the Empirical Literature. Fiscal Studies 35(4), p. 421-448.

[13] Francois, J., Hoekman, B., 2010. Services trade and policy. Journal of Economic Literature 48(3), p. 642-692.

[14] Grubert, H., 1998. Taxes and the division of foreign operating income among royalties, interest, dividends and retained earnings. Journal of Public Economics 68, p. 269-290.

[15] Hanlon, M., Maydew, E., Thornock, J., 2015. Taking the long way home: U.S. tax evasion and offshore investments in U.S. equity and debt markets. Journal of Finance, forthcoming

[16] Haskel, J. Lawrence, R., Leamer, E., Slaughter, M. 2012. Globalization and U.S. wages: Modifying classic theory to explain recent facts. Journal of Economic Perspectives 26(2), p.119-140

[17] Hebous, S., Lipatov, V., 2014. A journey from a corruption port to a tax haven. Journal of Comparative Economics , 42(3), p. 739-754

[18] Hines J., Rice, E., 1994. Foreign tax havens and American business. Quarterly Journal of Economics 109(1), p. 149-182.

[19] Hines, J., 2014. How serious a problem is base erosion and profit shifting? Canadian Tax Journal 62(2), p. 443-53.

[20] Hines, J., 2010. Treasure islands. Journal of Economic Perspectives 24(4), p. 103-26.

[21] Huizinga H., Laeven, L., 2008. International profit shifting within multinationals: A multicountry perspective. Journal of Public Economics 92, p. 1164-1182.

[22] Huizinga, H., Laeven, L., Nicodeme, G., 2008. Capital structure and international debt shifting. Journal of Financial Economics 88, 80-118

[23] Jensen, J., 2011. Global trade in services: Fear, facts, and offshoring. Peterson Institute for International Economics. 
[24] Johannesen, N., 2012. Optimal fiscal barriers to international economic integration in the presence of tax havens. Journal of Public Economics 96, p. 400-416.

[25] Johannesen, N., 2014. Tax evasion and Swiss bank deposits. Journal of Public Economics 111, p. $46-62$

[26] Johannesen, N., 2014. Tax avoidance with cross-border hybrid instruments. Journal of Public Economics 112, p. 40-52

[27] Johannesen, N., Zucman, G., 2014. The end of bank secrecy? An evaluation of the G20 tax haven crackdown. American Economic Journal: Economic Policy 6(1), p. 65-91.

[28] Karkinsky, T., Riedel, N., 2012. Corporate taxation and the choice of patent location within multinational firms. Journal of International Economics 88, 176-185.

[29] Kelle M., Kleinert, J., Raff, H., Toubal, F., 2013. Cross-border and foreign affiliate sales of services: Evidence from German microdata. The World Economy 36, 1373-1392.

[30] Kleinbard, E. , 2011. Stateless income. Florida Tax Review 11(9), p. 700-774.

[31] Lewellen, K. and Robinson, L., 2013. Internal ownership structures of U.S. multinational firms. Unpublished working paper

[32] Lipponer, A., 2011. Microdatabase direct investment - Midi. Technical Documentation. Deutsche Bundesbank, Frankfurt.

[33] Liu, R., Trefler, D., 2008. Much ado about nothing: American jobs and the rise of services outsourcing to China and India. NBER Working Paper No. 14061.

[34] Mintz, J., Weichenrieder, A., 2010. The indirect side of direct investment. MIT Press, MA.

[35] OECD, 2013. Addressing base erosion and profit shifting.

[36] Silva, J. M. C. S., Tenreyro, S., 2006. The log of gravity. Review of Economics and Statistics $88(4), 641-658$.

[37] Slemrod, J., 2008. Why is Elvis on Burkina Faso postage stamps? Cross-country evidence on the commercialization of state sovereignty Journal of Empirical Legal Studies 5(4), $683-712$.

[38] WTO, 2013. International Trade Statistics. 
[39] Zucman, G., 2014. Taxing across borders: Tracking personal wealth and corporate profits. Journal of Economic Perspectives, forthcoming. 
Table 1: Gravity model of aggregate trade flows

\begin{tabular}{|c|c|c|c|c|}
\hline & $\begin{array}{c}(1) \\
\text { Services }\end{array}$ & $\begin{array}{c}(2) \\
\text { Goods }\end{array}$ & $\begin{array}{c}(3) \\
\text { Services } \\
\end{array}$ & $\begin{array}{c}(4) \\
\text { Goods }\end{array}$ \\
\hline Haven & $\begin{array}{l}1.79^{\star \star \star} \\
(0.25)\end{array}$ & $\begin{array}{c}0.15 \\
(0.17)\end{array}$ & & \\
\hline One haven & & & $\begin{array}{c}1.67^{\star \star \star} \\
(0.23)\end{array}$ & $\begin{array}{c}0.14 \\
(0.17)\end{array}$ \\
\hline Two havens & & & $\begin{array}{c}4.21^{\star * \star} \\
(0.61)\end{array}$ & $\begin{array}{c}0.26 \\
(0.50)\end{array}$ \\
\hline Product of GDP (in logs) & $\begin{array}{l}0.96^{\star \star \star} \\
(0.04)\end{array}$ & $\begin{array}{l}1.03^{\star \star \star} \\
(0.03)\end{array}$ & $\begin{array}{c}0.97^{\star \star \star} \\
(0.04)\end{array}$ & $\begin{array}{l}1.03^{\star \star \star} \\
(0.03)\end{array}$ \\
\hline Distance (in logs) & $\begin{array}{c}-0.82^{\star \star \star} \\
(0.10)\end{array}$ & $\begin{array}{c}-0.93^{\star \star \star} \\
(0.08)\end{array}$ & $\begin{array}{c}-0.82^{\star \star \star} \\
(0.10)\end{array}$ & $\begin{array}{c}-0.93^{\star \star \star} \\
(0.08)\end{array}$ \\
\hline Contiguity & $\begin{array}{c}0.10 \\
(0.33)\end{array}$ & $\begin{array}{l}0.52^{\star \star} \\
(0.22)\end{array}$ & $\begin{array}{c}0.14 \\
(0.32)\end{array}$ & $\begin{array}{l}0.52^{\star *} \\
(0.22)\end{array}$ \\
\hline Common language (official) & $\begin{array}{l}1.54^{\star \star \star} \\
(0.33)\end{array}$ & $\begin{array}{l}0.86^{\star \star \star} \\
(0.20)\end{array}$ & $\begin{array}{l}1.48^{\star \star \star} \\
(0.36)\end{array}$ & $\begin{array}{l}0.86^{\star \star \star} \\
(0.21)\end{array}$ \\
\hline Same country & $\begin{array}{l}1.18^{\star \star \star} \\
(0.38)\end{array}$ & $\begin{array}{c}1.02^{\star \star \star} \\
(0.33)\end{array}$ & $\begin{array}{c}1.20^{\star \star \star} \\
(0.38)\end{array}$ & $\begin{array}{l}1.02^{\star \star \star} \\
(0.33)\end{array}$ \\
\hline Constant & $\begin{array}{c}-39.36^{\star \star \star} \\
(2.03)\end{array}$ & $\begin{array}{c}-40.39^{\star \star \star} \\
(1.88)\end{array}$ & $\begin{array}{c}-39.89^{\star \star \star} \\
(2.04)\end{array}$ & $\begin{array}{c}-40.40^{\star \star \star} \\
(1.89)\end{array}$ \\
\hline $\begin{array}{l}\text { Observations } \\
\text { R-squared }\end{array}$ & $\begin{array}{c}3,335 \\
0.73\end{array}$ & $\begin{array}{c}4,208 \\
0.78\end{array}$ & $\begin{array}{c}3,335 \\
0.74\end{array}$ & $\begin{array}{c}4,208 \\
0.78\end{array}$ \\
\hline
\end{tabular}

Note: "Haven" is a dummy coded one if at least one of the two countries is on the tax haven list of Hines (2010); "One haven" is

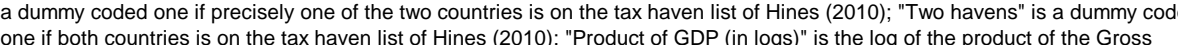

Domestic Product of the two countries: "Distance (in logs) is the log of the geodesic distance between the most important city in

each the two countries; "Contiguity" is a dummy coded one if the two countries share a border; "Common language" is a dummy

coded one if the two countries share an official language; "Same country" is a dummy coded one if the two countries have been

part of the same country. Trade information is from OECD Trade Statistics; GDP is from World Development Indicators

supplemented with information from the CIA World Factbook; All other variables are from the CEPII database. Standard errors

clustered at the level of the reporting country and the partner country in parentheses: ${ }^{\star \star \star} p<0.01,{ }^{\star \star} p<0.05,{ }^{*} p<0.1$ 
Table 2: Summary statistics for broad service groups (€ million)

\begin{tabular}{|c|c|c|c|c|c|c|c|c|c|c|c|c|}
\hline & \multicolumn{5}{|c|}{ Business Services } & \multicolumn{2}{|c|}{ Financial servies } & \multicolumn{4}{|c|}{ Transport services } & \multirow[t]{2}{*}{ Total } \\
\hline & Construction & Information & Communication & $\begin{array}{l}\text { Intellectual } \\
\text { property }\end{array}$ & $\begin{array}{c}\text { Other } \\
\text { business }\end{array}$ & Insurance & Financial & Air & Sea & Road & Inland water & \\
\hline Total imports & 5,479 & 11,717 & 5,491 & 14,462 & 39,492 & 7,362 & 6,826 & 20,895 & 18,343 & 12,662 & 5,415 & 247,170 \\
\hline - from tax havens & 452 & 3,418 & 893 & 1,893 & 7,371 & 3,314 & 2,010 & 1,579 & 4,419 & 1,236 & 535 & 36,734 \\
\hline - subsidiaries & 74 & 753 & 145 & 543 & 1,957 & 1,025 & 1,126 & 444 & 565 & 314 & 4 & 8,640 \\
\hline - parent & 18 & 190 & 38 & 537 & 763 & 357 & 111 & 7 & 551 & 32 & 1 & 2,912 \\
\hline - third parties & 359 & 2,475 & 710 & 812 & 4,651 & 1,932 & 774 & 1,129 & 3,303 & 890 & 530 & 25,182 \\
\hline - from other countries & 5,027 & 8,298 & 4,599 & 12,570 & 32,121 & 4,048 & 4,815 & 19,316 & 13,924 & 824 & 4,880 & 210,436 \\
\hline - subsidiaries & 1,469 & 3,256 & 963 & 3,371 & 10,889 & 857 & 2,996 & 9,185 & 4,484 & 318 & 254 & 66,371 \\
\hline - parent & 110 & 1,509 & 1,270 & 3,346 & 4,094 & 489 & 336 & 665 & 707 & 10 & 325 & 15,904 \\
\hline - third parties & 3,448 & 3,534 & 2,365 & 5,853 & 17,139 & 2,702 & 1,483 & 9,466 & 8,733 & 497 & 4,301 & 128,160 \\
\hline Total exports & 8,950 & 13,915 & 4,101 & 20,031 & 31,443 & 24,711 & 10,554 & 13,412 & 26,931 & 855 & 458 & 221,077 \\
\hline - to tax havens & 667 & 1,671 & 853 & 2,592 & 8,341 & 2,607 & 3,517 & 888 & 4,706 & 31 & 64 & 40,094 \\
\hline - subsidiaries & 108 & 564 & 103 & 619 & 762 & 1,345 & 1,878 & 400 & 247 & 8 & 0 & 6,939 \\
\hline - parent & 28 & 148 & 10 & 815 & 450 & 283 & 135 & 0 & 15 & 0 & 0 & 3,434 \\
\hline - third parties & 531 & 959 & 739 & 1,159 & 7,129 & 979 & 1,503 & 488 & 4,443 & 23 & 64 & 29,722 \\
\hline - to other countries & 8,283 & 12,244 & 3,248 & 17,439 & 23,102 & 22,104 & 7,037 & 12,524 & 22,226 & 11,426 & 395 & 180,982 \\
\hline - subsidiaries & 2,577 & 7,550 & 566 & 5,092 & 4,910 & 17,112 & 2,525 & 9,771 & 6,025 & 1,754 & 39 & 61,379 \\
\hline - parent & 322 & 1,012 & 864 & 4,088 & 3,577 & 809 & 1,060 & 11 & 613 & 514 & 4 & 15,964 \\
\hline - third parties & 5,384 & 3,681 & 1,818 & 8,259 & 14,615 & 4,183 & 3,453 & 2,742 & 15,588 & 9,158 & 352 & 103,639 \\
\hline
\end{tabular}

where total trade is below $€ 5$ billion: Repairs, Personnel services, Rail transport and Transport by pipeline and electricity transmission. It also omits the residual category Other services. The aggregation of service categories follows the

Development (511). In Insurance, we only include insurance premiums and not transfers settling claims. The reported categories do not sum to Total because of the omitted categories and the omission of transfers settling claims in Insurance. 
Table 3: Summary statistics for narrow service groups ( $€$ million)

\begin{tabular}{|c|c|c|c|c|c|c|c|c|c|c|}
\hline & & & & \multirow{2}{*}{\multicolumn{7}{|c|}{$\begin{array}{l}\text { Other business services } \\
\end{array}$}} \\
\hline & \multicolumn{3}{|c|}{ Intellectual Property } & & & & & & & \\
\hline & Patents & Trademarks & $\begin{array}{c}\text { Research \& } \\
\text { Development }\end{array}$ & $\begin{array}{l}\text { Technical } \\
\text { services }\end{array}$ & $\begin{array}{c}\text { Headquarter } \\
\text { services }\end{array}$ & $\begin{array}{c}\text { Commission } \\
\text { fees }\end{array}$ & Subsidies & $\begin{array}{l}\text { Overhead } \\
\text { expenses }\end{array}$ & Advertising & $\begin{array}{c}\text { Operational } \\
\text { leasing }\end{array}$ \\
\hline Total imports & 4,561 & 1,722 & 7,679 & 8,860 & 15,101 & 5,237 & 2,602 & 461 & 4,559 & 2,283 \\
\hline - from tax havens & 584 & 474 & 799 & 1,141 & 2,990 & 879 & 185 & 27 & 1,133 & 968 \\
\hline - subsidiaries & 94 & 47 & 402 & 412 & 780 & 210 & 91 & 1 & 172 & 288 \\
\hline - parent & 229 & 205 & 102 & 35 & 506 & 41 & 2 & 23 & 139 & 16 \\
\hline - third parties & 261 & 222 & 295 & 693 & 1,704 & 627 & 92 & 4 & 821 & 664 \\
\hline - from other countries & 3,977 & 1,248 & 6,880 & 7,719 & 12,111 & 4,359 & 2,417 & 434 & 3,426 & 1,315 \\
\hline - subsidiaries & 598 & 185 & 2,581 & 3,307 & 3,198 & 1,245 & 1,317 & 5 & 1,336 & 455 \\
\hline - parent & 2,384 & 447 & 486 & 620 & 2,732 & 141 & 69 & 301 & 132 & 94 \\
\hline - third parties & 995 & 616 & 3,813 & 3,792 & 6,181 & 2,973 & 1,031 & 127 & 1,957 & 766 \\
\hline Total exports & 6,647 & 2,072 & 11,072 & 9,887 & 11,060 & 2,290 & 904 & 1,242 & 3,990 & 1,730 \\
\hline - to tax havens & 803 & 186 & 1,549 & 1,930 & 2,753 & 1,288 & 112 & 174 & 1,699 & 321 \\
\hline - subsidiaries & 337 & 21 & 260 & 176 & 201 & 63 & 4 & 154 & 143 & 17 \\
\hline - parent & 187 & 27 & 601 & 60 & 298 & 29 & 26 & 0 & 24 & 11 \\
\hline - third parties & 279 & 138 & 688 & 1,693 & 2,254 & 1,196 & 82 & 20 & 1,531 & 292 \\
\hline - to other countries & 5,843 & 1,886 & 9,524 & 7,957 & 8,306 & 1,002 & 792 & 1,068 & 2,291 & 1,409 \\
\hline - subsidiaries & 2,303 & 668 & 2,121 & 1,777 & 1,521 & 226 & 42 & 884 & 205 & 242 \\
\hline - parent & 332 & 161 & 3,587 & 1,016 & 1,841 & 161 & 187 & 36 & 249 & 80 \\
\hline - third parties & 3,208 & 1,057 & 3,816 & 5,164 & 4,945 & 615 & 563 & 148 & 1,838 & 1,086 \\
\hline
\end{tabular}

Source: Microdatabase Statistics on International Trade in Service 2011, Deutsche Bundesbank and Microdatabase Direct Investment 2011, Deutsche Bundesbank, own calculations. The table does not
include the following service categories where total trade is below 11 billion: Artistic copyrights, Payments for entrepreneurial work and Disposal services. The category Headquarter services is referred to
as Commercial, organisational and administrtative services in the official nomenclature. 
Table 4: Imports

Business Service

Financial servies

Transport services

Construction Information Communication Intellectual

Other

Insurance

Air

Sea

Road

Inland water

\begin{tabular}{|c|c|c|c|c|c|c|c|c|c|c|c|}
\hline Haven & $\begin{array}{c}0.001^{\star \star \star} \\
(0.000)\end{array}$ & $\begin{array}{c}0.005^{\star \star \star} \\
(0.000)\end{array}$ & $\begin{array}{l}0.001^{\star \star \star} \\
(0.000)\end{array}$ & $\begin{array}{l}0.003^{\star \star *} \\
(0.000)\end{array}$ & $\begin{array}{c}0.009^{\star \star \star} \\
(0.000)\end{array}$ & $\begin{array}{l}0.001^{\star \star *} \\
(0.000)\end{array}$ & $\begin{array}{c}0.002^{\star \star *} \\
(0.000)\end{array}$ & $\begin{array}{c}0.002^{\star \star *} \\
(0.000)\end{array}$ & $\begin{array}{c}0.013^{\star \star \star} \\
(0.000)\end{array}$ & $\begin{array}{l}0.001^{\star \star *} \\
(0.000)\end{array}$ & $\begin{array}{l}0.001^{\star \star \star} \\
(0.000)\end{array}$ \\
\hline Affilliate & $\begin{array}{l}0.014^{\star \star \star} \\
(0.003)\end{array}$ & $\begin{array}{l}0.056^{\star \star \star} \\
(0.004)\end{array}$ & $\begin{array}{l}0.014^{\star \star \star} \\
(0.002)\end{array}$ & $\begin{array}{c}0.050^{\star \star \star} \\
(0.004)\end{array}$ & $\begin{array}{c}0.193^{\star \star *} \\
(0.006)\end{array}$ & $\begin{array}{l}0.026^{\star \star \star} \\
(0.002)\end{array}$ & $\begin{array}{l}0.023^{\star \star \star} \\
(0.002)\end{array}$ & $\begin{array}{l}0.006^{\star \star \star} \\
(0.002)\end{array}$ & $\begin{array}{c}-0.013^{\star \star \star} \\
(0.002)\end{array}$ & $\begin{array}{l}0.026^{\star \star \star} \\
(0.003)\end{array}$ & $\begin{array}{c}0.004^{\star \star \star} \\
(0.001)\end{array}$ \\
\hline Haven $\times$ Affiliate & $\begin{array}{c}-0.008^{\star \star \star \star} \\
(0.003)\end{array}$ & $\begin{array}{l}0.028^{\star \star \star} \\
(0.006)\end{array}$ & $\begin{array}{l}0.005^{\star} \\
(0.003)\end{array}$ & $\begin{array}{l}0.025^{\star \star \star} \\
(0.005)\end{array}$ & $\begin{array}{c}0.023^{\star \star \star} \\
(0.008)\end{array}$ & $\begin{array}{l}-0.002 \\
(0.004)\end{array}$ & $\begin{array}{l}0.020^{\star \star \star} \\
(0.005)\end{array}$ & $\begin{array}{c}0.000 \\
(0.003)\end{array}$ & $\begin{array}{c}0.009^{\star \star \star} \\
(0.003)\end{array}$ & $\begin{array}{l}-0.004 \\
(0.004)\end{array}$ & $\begin{array}{l}-0.002 \\
(0.002)\end{array}$ \\
\hline Distance (in logs) & $\begin{array}{c}-0.001^{\star \star \star} \\
(0.000)\end{array}$ & $\begin{array}{c}-0.003^{\star \star \star \star} \\
(0.000)\end{array}$ & $\begin{array}{c}-0.001^{\star \star \star} \\
(0.000)\end{array}$ & $\begin{array}{c}-0.002^{\star \star \star} \\
(0.000)\end{array}$ & $\begin{array}{c}-0.003^{\star \star \star} \\
(0.000)\end{array}$ & $\begin{array}{c}-0.002^{\star \star \star} \\
(0.000)\end{array}$ & $\begin{array}{c}-0.001^{\star \star \star} \\
(0.000)\end{array}$ & $\begin{array}{c}-0.000^{\star \star \star \star} \\
(0.000)\end{array}$ & $\begin{array}{c}-0.005^{\star \star \star} \\
(0.000)\end{array}$ & $\begin{array}{c}-0.004^{\star \star \star} \\
(0.000)\end{array}$ & $\begin{array}{c}-0.001^{\star \star \star} \\
(0.000)\end{array}$ \\
\hline GDP (in logs) & $\begin{array}{l}0.001^{\star \star \star} \\
(0.000)\end{array}$ & $\begin{array}{l}0.002^{\star \star \star} \\
(0.000)\end{array}$ & $\begin{array}{l}0.001^{\star \star \star} \\
(0.000)\end{array}$ & $\begin{array}{l}0.002^{\star \star \star} \\
(0.000)\end{array}$ & $\begin{array}{l}0.006^{\star \star \star} \\
(0.000)\end{array}$ & $\begin{array}{l}0.001^{\star \star \star} \\
(0.000)\end{array}$ & $\begin{array}{l}0.001^{\star \star \star} \\
(0.000)\end{array}$ & $\begin{array}{l}0.001^{\star \star \star} \\
(0.000)\end{array}$ & $\begin{array}{l}0.005^{\star \star \star} \\
(0.000)\end{array}$ & $\begin{array}{c}0.002^{\star \star \star} \\
(0.000)\end{array}$ & $\begin{array}{c}0.001^{\star \star *} \\
(0.000)\end{array}$ \\
\hline Contiguity & $\begin{array}{l}0.018^{\star \star \star} \\
(0.001)\end{array}$ & $\begin{array}{l}0.010^{\star \star \star} \\
(0.001)\end{array}$ & $\begin{array}{c}0.002^{\star \star \star} \\
(0.001)\end{array}$ & $\begin{array}{c}0.016 * \star * \\
(0.001)\end{array}$ & $\begin{array}{l}0.039^{\star \star \star} \\
(0.001)\end{array}$ & $\begin{array}{c}0.004^{\star \star \star} \\
(0.001)\end{array}$ & $\begin{array}{l}0.003^{\star \star *} \\
(0.001)\end{array}$ & $\begin{array}{c}0.007^{\star \star \star *} \\
(0.001)\end{array}$ & $\begin{array}{c}0.037^{\star \star \star} \\
(0.001)\end{array}$ & $\begin{array}{c}0.037 * \star * \\
(0.001)\end{array}$ & $\begin{array}{c}0.011^{\star \star *} \\
(0.001)\end{array}$ \\
\hline Common language & $\begin{array}{l}0.007^{\star \star \star} \\
(0.001)\end{array}$ & $\begin{array}{l}0.022^{\star \star \star} \\
(0.001)\end{array}$ & $\begin{array}{c}0.006^{\star \star \star} \\
(0.001)\end{array}$ & $\begin{array}{c}0.011^{\star \star \star} \\
(0.001)\end{array}$ & $\begin{array}{l}0.027^{\star \star \star} \\
(0.001)\end{array}$ & $\begin{array}{c}0.006^{\star \star \star} \\
(0.001)\end{array}$ & $\begin{array}{c}0.014^{\star \star \star} \\
(0.001)\end{array}$ & $\begin{array}{c}0.001 \\
(0.001)\end{array}$ & $\begin{array}{c}-0.039 * \star \star \\
(0.001)\end{array}$ & $\begin{array}{c}0.001 \\
(0.001)\end{array}$ & $\begin{array}{c}0.000 \\
(0.001)\end{array}$ \\
\hline Observations & $1,746,694$ & $2,131,672$ & $1,491,000$ & $1,951,488$ & $4,541,160$ & $1,477,212$ & $1,707,800$ & $1,527,200$ & $2,017,405$ & $1,884,000$ & $1,488,950$ \\
\hline R-squared & 0.014 & 0.029 & 0.008 & 0.025 & 0.058 & 0.013 & 0.014 & 0.007 & 0.026 & 0.029 & 0.008 \\
\hline Number of firms & 8,647 & 10,988 & 7,455 & 9,856 & 22,152 & 7,942 & 8,539 & 7,636 & 9,841 & 9,420 & 7,675 \\
\hline Parent fixed effects & Yes & Yes & Yes & Yes & Yes & Yes & Yes & Yes & Yes & Yes & Yes \\
\hline Unconditional prob of trade & 0.003 & 0.004 & 0.002 & 0.005 & 0.012 & 0.001 & 0.002 & 0.003 & 0.012 & 0.006 & 0.002 \\
\hline
\end{tabular}

"Note: The dependent variable is "Import" which is a dummy coded one if the German firm imports the service from the foreign country; "Haven" is a dummy coded one if the foreign country is on the tax haven list of Hines (2010); "Affiliate" is a dummy coded one if the German firm has a subsidiary or a parent in the foreign country; "GDP (in logs)" is the log of the Gross Domestic Product of the foreign country; "Distance (in logs) is the log of the geodesic distance between Berlin and the most important city of the foreign country; "Contiguity" is a dummy coded one if the foreign country shares a border with Germany," "Common language "is a dummy coded one if the foreign Direct Investment (MiDi) provided by the Deutsche Bundeshank (see Lipponer, 2011): GDP is from World Development Indicators supplemented with information from the CIA World Factbook; All other variables are from the Direct Investment (MiDI) provided bl the Deutsche Bundesbank (see Lipponer, 2011); GDP is from World
CEPII database. Standard errors clustered at the firm-level in parentheses $\left.{ }^{* \star *} p<0.01,{ }^{* *} p<0.05,{ }^{*} p<0.1\right)$. 
Table 5: Exports

\begin{tabular}{|c|c|c|c|c|c|c|c|c|c|c|c|}
\hline & \multicolumn{5}{|c|}{ Business Services } & \multicolumn{2}{|c|}{ Financial servies } & \multicolumn{4}{|c|}{ Transport services } \\
\hline & Construction & Information & Communication & $\begin{array}{c}\text { Intellectual } \\
\text { property }\end{array}$ & $\begin{array}{c}\text { Other } \\
\text { business }\end{array}$ & Insurance & Financial & Air & Sea & Road & Inland water \\
\hline Haven & $\begin{array}{l}0.001^{\star \star *} \\
(0.000)\end{array}$ & $\begin{array}{c}0.002^{\star \star \star} \\
(0.000)\end{array}$ & $\begin{array}{c}0.000^{\star \star \star} \\
(0.000)\end{array}$ & $\begin{array}{c}0.002^{\star * *} \\
(0.000)\end{array}$ & $\begin{array}{l}0.003^{\star \star *} \\
(0.000)\end{array}$ & $\begin{array}{c}0.001^{\star \star \star} \\
(0.000)\end{array}$ & $\begin{array}{c}0.004^{\star \star \star} \\
(0.000)\end{array}$ & $\begin{array}{c}0.000^{\star * \star} \\
(0.000)\end{array}$ & $\begin{array}{c}0.003^{\star \star \star} \\
(0.000)\end{array}$ & $\begin{array}{c}0.000^{\star \star *} \\
(0.000)\end{array}$ & $\begin{array}{c}0.000^{\star \star *} \\
(0.000)\end{array}$ \\
\hline Affilliate & $\begin{array}{c}0.013^{\star \star \star} \\
(0.003)\end{array}$ & $\begin{array}{l}0.051^{\star \star \star} \\
(0.005)\end{array}$ & $\begin{array}{l}0.007 \star \star \star \\
(0.002)\end{array}$ & $\begin{array}{c}0.048^{\star \star \star} \\
(0.005)\end{array}$ & $\begin{array}{l}0.132^{\star \star \star} \\
(0.006)\end{array}$ & $\begin{array}{c}0.011^{\star \star \star} \\
(0.002)\end{array}$ & $\begin{array}{c}0.013^{\star \star \star} \\
(0.002)\end{array}$ & $\begin{array}{c}0.000 \\
(0.001)\end{array}$ & $\begin{array}{c}-0.003^{\star \star \star} \\
(0.001)\end{array}$ & $\begin{array}{c}0.001 \\
(0.001)\end{array}$ & $\begin{array}{c}-0.001^{\star * *} \\
(0.000)\end{array}$ \\
\hline Haven $\times$ Affiliate & $\begin{array}{c}-0.015^{\star \star *} \\
(0.003)\end{array}$ & $\begin{array}{c}-0.011^{\star *} \\
(0.005)\end{array}$ & $\begin{array}{l}-0.001 \\
(0.002)\end{array}$ & $\begin{array}{c}-0.022^{\star \star *} \\
(0.005)\end{array}$ & $\begin{array}{c}-0.015^{\star *} \\
(0.007)\end{array}$ & $\begin{array}{c}0.003 \\
(0.003)\end{array}$ & $\begin{array}{c}0.003 \\
(0.005)\end{array}$ & $\begin{array}{c}-0.001^{\star \star} \\
(0.000)\end{array}$ & $\begin{array}{c}-0.005^{\star \star \star} \\
(0.001)\end{array}$ & $\begin{array}{c}-0.001^{\star *} \\
(0.000)\end{array}$ & $\begin{array}{c}-0.002^{* * *} \\
(0.000)\end{array}$ \\
\hline Distance (in logs) & $\begin{array}{c}-0.001^{\star * *} \\
(0.000)\end{array}$ & $\begin{array}{c}-0.001^{\star \star \star} \\
(0.000)\end{array}$ & $\begin{array}{c}-0.001^{\star \star \star} \\
(0.000)\end{array}$ & $\begin{array}{c}-0.001^{\star \star *} \\
(0.000)\end{array}$ & $\begin{array}{c}-0.002^{\star \star \star *} \\
(0.000)\end{array}$ & $\begin{array}{c}-0.001^{\star \star *} \\
(0.000)\end{array}$ & $\begin{array}{c}-0.001^{\star \star \star} \\
(0.000)\end{array}$ & $\begin{array}{c}-0.000^{* \star \star} \\
(0.000)\end{array}$ & $\begin{array}{c}-0.001^{\star \star \star} \\
(0.000)\end{array}$ & $\begin{array}{c}-0.000^{* * *} \\
(0.000)\end{array}$ & $\begin{array}{c}-0.000^{* * *} \\
(0.000)\end{array}$ \\
\hline GDP (in logs) & $\begin{array}{c}0.001^{\star \star \star} \\
(0.000)\end{array}$ & $\begin{array}{c}0.002^{\star \star \star} \\
(0.000)\end{array}$ & $\begin{array}{c}0.000 * \star \star \\
(0.000)\end{array}$ & $\begin{array}{c}0.002^{\star \star \star} \\
(0.000)\end{array}$ & $\begin{array}{c}0.002^{\star \star *} \\
(0.000)\end{array}$ & $\begin{array}{c}0.001^{\star \star \star} \\
(0.000)\end{array}$ & $\begin{array}{c}0.001^{\star \star \star} \\
(0.000)\end{array}$ & $\begin{array}{c}0.000^{\star \star \star} \\
(0.000)\end{array}$ & $\begin{array}{c}0.001^{\star \star \star} \\
(0.000)\end{array}$ & $\begin{array}{c}0.000 * \star \star \\
(0.000)\end{array}$ & $\begin{array}{c}0.000 * \star * \\
(0.000)\end{array}$ \\
\hline Contiguity & $\begin{array}{c}0.015^{\star \star \star} \\
(0.001)\end{array}$ & $\begin{array}{l}0.013^{\star \star \star} \\
(0.001)\end{array}$ & $\begin{array}{l}0.002^{\star \star \star} \\
(0.000)\end{array}$ & $\begin{array}{c}0.011^{\star \star \star} \\
(0.001)\end{array}$ & $\begin{array}{c}0.021^{\star \star \star} \\
(0.001)\end{array}$ & $\begin{array}{c}0.006^{\star \star \star} \\
(0.001)\end{array}$ & $\begin{array}{c}0.010 * \star \star \\
(0.001)\end{array}$ & $\begin{array}{c}0.001^{\star \star \star} \\
(0.000)\end{array}$ & $\begin{array}{c}0.012^{\star \star \star} \\
(0.001)\end{array}$ & $\begin{array}{c}0.001^{\star \star \star} \\
(0.000)\end{array}$ & $\begin{array}{l}0.003^{\star \star \star} \\
(0.000)\end{array}$ \\
\hline Common language & $\begin{array}{c}0.008^{\star \star *} \\
(0.001)\end{array}$ & $\begin{array}{c}0.011^{\star \star \star} \\
(0.001)\end{array}$ & $\begin{array}{l}0.002^{* \star *} \\
(0.000)\end{array}$ & $\begin{array}{c}0.003^{\star \star *} \\
(0.001)\end{array}$ & $\begin{array}{c}0.010^{\star * \star *} \\
(0.001)\end{array}$ & $\begin{array}{c}0.005^{\star \star \star *} \\
(0.001)\end{array}$ & $\begin{array}{c}0.026^{\star \star *} \\
(0.001)\end{array}$ & $\begin{array}{c}0.001^{\star * \star} \\
(0.000)\end{array}$ & $\begin{array}{c}-0.004^{\star * *} \\
(0.001)\end{array}$ & $\begin{array}{c}0.000 \\
(0.000)\end{array}$ & $\begin{array}{c}0.000 \\
(0.000)\end{array}$ \\
\hline Observations & $1,746,694$ & $2,131,672$ & $1,491,000$ & $1,951,488$ & $4,541,160$ & $1,424,654$ & $1,707,800$ & $1,527,200$ & $2,017,405$ & $1,884,000$ & $1,488,950$ \\
\hline R-squared & 0.013 & 0.021 & 0.004 & 0.018 & 0.036 & 0.008 & 0.019 & 0.001 & 0.008 & 0.001 & 0.003 \\
\hline Number of firms & 8,647 & 10,988 & 7,455 & 9,856 & 22,152 & 7,018 & 8,539 & 7,636 & 9,841 & 9,420 & 7,675 \\
\hline Parent fixed effects & Yes & Yes & Yes & Yes & Yes & Yes & Yes & Yes & Yes & Yes & Yes \\
\hline Unconditional prob of trade & 0.004 & 0.004 & 0.001 & 0.003 & 0.006 & 0.002 & 0.003 & 0.001 & 0.003 & 0.000 & 0.000 \\
\hline
\end{tabular}

Note: The dependent variable is "Export" Which is a dummy coded one if the German firm exports the service to the foreign country; "Haven" is a dummy coded one if the foreign country is on the tax haven list of Hines (2010); "Aiftilate" is a dummetween Berlin and the most important city of the foreign country; "Contiguity" is a dummy coded one if the foreign country shares a border with Germany; "Common language" is a dummy coded one if the foreign country has German as official language. Trade information is from Statistics on International Trade in Service (SITS) provided by the Deutsche Bundesbank (see Biewen et al., 2013); Affiliate information is from Microdatabase

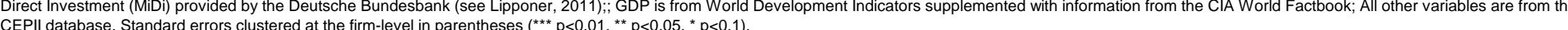




\section{Panel A: Manufacturing firms}

$0.002^{* * *}$

\section{Affilliate}

$0.001^{\star \star *}$

$0.005^{\star \star *} \quad 0.013^{\star \star \star *}$

$0.001^{\star \star \star} \quad 0.001^{\star \star \star}$

$0.001^{\star \star \star}$

Haven $\times$ Affiliate

$0.041^{* * *}$

$(0.000) \quad(0.000)$

$(0.000) \quad(0.000)$

(0.000) (0.000)

$0.002^{\star \star \star} \quad 0.001^{\star \star \star} \quad 0.001^{\star \star \star}$

$\begin{array}{lllll}0.041^{\star \star \star} & 0.080^{\star \star \star} & 0.016^{\star \star \star} & 0.126^{\star \star \star} & 0.317^{\star} \\ (0.008) & (0.007) & (0.003) & (0.009) & (0.011)\end{array}$

$0.041^{\star \star \star} \quad 0.014^{\star \star \star}$

$(0.000)$

$\begin{array}{lll}(0.000) & (0.000) \quad(0.000)\end{array}$

$\begin{array}{lllll}(0.008) & (0.007) & (0.003) & (0.009) & (0.011)\end{array}$

$(0.003) \quad(0.003)$

$\begin{array}{llll}0.019^{\star *} & 0.023^{\star \star \star} & 0.075^{\star \star \star} & 0.013^{\star \star} \\ (0.004) & (0.004) & (0.008) & (0.002) \\ 0.014 & 0.030 & 0.032^{\star *} & 0.009\end{array}$

$\begin{array}{lllll}(0.010) & (0.015) & (0.008) & (0.016) & (0.017)\end{array}$

$(0.010) \quad(0.007)$

$\begin{array}{cccc}0.014 & 0.030^{\star \star \star} & 0.032^{\star *} & 0.009 \\ (0.009) & (0.010) & (0.013) & (0.008)\end{array}$

Observations

$534,694 \quad 508,474 \quad 372,000$

$641,520 \quad 1,417,165$

$394,134 \quad 373,600$

R-squared

$\begin{array}{lll}0.024 & 0.044 & 0.010 \\ 2,647 & 2,621 & 1,860\end{array}$

$0.057 \quad 0.088$

$\begin{array}{cr}394,134 & 373,600 \\ 0.023 & 0.008\end{array}$

$381,400 \quad 424,965 \quad 530,600 \quad 374,226$

Number of firms

service firms

Panel

$\begin{array}{lll}0.000 & 0.005^{\star \star *} & 0.002^{\star \star *}\end{array}$

Affilliate

$\begin{array}{lll}0.0002 * \star & 0.006^{\star \star}\end{array}$

$2,119 \quad 1,868$

1,907

0.016
2,073

2,653

.011

Haven $\times$ Affiliate

$0.003^{\star \star} \quad 0.046^{\star \star \star} \quad 0.013^{\star \star \star}$

$0.002^{\star * \star} \quad 0.002^{\star * \star}$

$\begin{array}{llll}0.002^{\star \star *} & 0.016^{\star * *} & 0.001^{* \star *} & 0.001^{\star * \star} \\ (0.000) & (0.000) & (0.000) & (0.000)\end{array}$

$(0.000) \quad(0.000)$

$\begin{array}{lllll}0.008^{\star * \star} & (0.004) & (0.002) & (0.002) & (0.006)\end{array}$

$(0.002) \quad(0.003)$

$\begin{array}{llll}0.001 & -0.025^{\star * *} & 0.004^{*} & -0.000 \\ (0.001) & (0.002) & (0.002) & (0.001)\end{array}$

$\begin{array}{lllll}-0.008^{\star \star *} & 0.009 & -0.000 & 0.002 & 0.022^{\star *} \\ (0.002) & (0.006) & (0.004) & (0.004) & (0.009)\end{array}$

$(0.004) \quad(0.006)$

$\begin{array}{ccc}-0.025^{\star \star \star} & 0.004^{*} & -0.000 \\ (0.002) & (0.002) & (0.001)\end{array}$

Observations

$1,212,000 \quad 1,623,198$

(0.002)

$(0.003)$

(0.003)

$-0.004^{*}$
$(0.002)$

R-squared

$\begin{array}{ll}0.011 & 0.025 \\ 6,000 & 8,367\end{array}$

0.008

$1,309,968 \quad 3,123,995$

$1,083,078 \quad 1,334,200$

$\begin{array}{cccc}1,145,800 & 1,592,440 & 1,353,400 & 1,114,724\end{array}$

$\begin{array}{ll}0.011 & 0.016 \\ 5,823 & 6,671\end{array}$

5,729

$\begin{array}{lll}0.030 & 0.022 & 0.007 \\ 7,768 & 6,767 & 5,746\end{array}$

\section{Panel C: Financial service firms}

Haven

$\begin{array}{ccc}-0.000 & 0.007^{\star \star \star} & 0.003^{\star \star \star} \\ (0.000) & (0.001) & (0.001) \\ 0.004 & 0.130^{\star \star \star} & 0.064^{\star \star \star}\end{array}$

\section{Affilliate}

Haven $\times$ Affiliate

$\begin{array}{lll}(0.003) & (0.020) & (0.012)\end{array}$

$0.000^{* *} \quad 0.012^{* \star *}$

$\begin{array}{cc}0.008^{\star \star *} & 0.011^{\star \star \star} \\ (0.001) & (0.002)\end{array}$

5,746

\section{Observations}

R-squared

$0.003-0.022-(0.012)$

$(0.000) \quad(0.002)$

$\begin{array}{ccc}0.001^{*} & 0.000 & 0.000 \\ (0.001) & (0.000) & (0.000)\end{array}$

$\begin{array}{ll}(0.000) & (0.002) \\ 0.011^{\star \star} & 0.339^{\star \star \star}\end{array}$

$\begin{array}{ll}(0.001) & (0.002) \\ 0.114^{\star \star \star} & 0.183^{\star \star \star}\end{array}$

$\begin{array}{ll}(0.020) & (0.030)\end{array}$

$\begin{array}{llll}0.005) & (0.021) & 0.013 & -0.145^{\star}\end{array}$

$\begin{array}{cc}-0.060^{\star \star} & 0.068^{\star *}\end{array}$

$\begin{array}{ll}-0.060 \times \star & 0.068 \\ (0.024) & (0.029)\end{array}$

$(0.001) \quad(0.000)$

$\left.\begin{array}{lllll}(0.005) & (0.021) & (0.016) & (0.011) & (0.027\end{array}\right)$

$52,638 \quad 56,600$

$\begin{array}{ccccc}57,166 & 54,902 & 56,600 & 56,034 & 58,015 \\ 0.004 & 0.075 & 0.031 & 0.010 & 0.162\end{array}$

Number of firms

283

283

283

0.010
283

0.162
283

0.061

0.104
283

Parent fixed effects

$\begin{array}{ll}\text { Yes } & \text { Yes } \\ \text { Yes } & \text { Yes }\end{array}$

Yes
Yes

Yes
Yes

Yes
Yes

Yes
Yes

Yes
Yes

Yes
Yes

$\begin{array}{lll}0.004 & (0.005) & (0.005)\end{array}$

$\begin{array}{lll}(0.006) & (0.003) & (0.003)\end{array}$

$58,015 \quad 56,600 \quad 54,902$

$\begin{array}{ccc}0.004 & 0.004 & 0.005 \\ 283 & 283 & 283\end{array}$

Note: The dependent variable is "Import" which is a dummy coded one if the German firm imports the service from the foreign country; "Haven" is a dummy coded one if the foreign country is on the tax haven list of $\mathrm{Hines}$ (2010); "Affiliate" is a dummy coded one if the German firm has a subsidiary or a parent in the foreign country. The set of unreported covariates is: "GDP (in logs)" is the log of the Gross Domestic Product of the foreign country; "Distance (in logs) is the log of the geodesic distance between Berlin and the most important city of the foreign country; "Contiguity" is a dummy coded one if the foreign country shares a border with Germany; "Common language" is a dummy coded one if the foreign country has German as oticial language. Trade information is from Statistics on "international Trade in Service (SITS) provided by the Deutsche Bundesbank (se

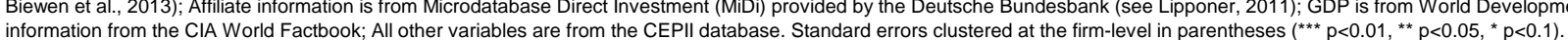


Table 7: Narrow service categories

\begin{tabular}{|c|c|c|c|c|c|c|c|c|c|c|}
\hline & \multicolumn{3}{|c|}{ Intellectual Property } & \multicolumn{7}{|c|}{$\begin{array}{l}\text { Other business services } \\
\end{array}$} \\
\hline & Patents & Trademarks & $\begin{array}{c}\text { Research \& } \\
\text { Development }\end{array}$ & $\begin{array}{c}\text { Technical } \\
\text { services } \\
\end{array}$ & $\begin{array}{c}\text { Headquarter } \\
\text { services }\end{array}$ & $\begin{array}{c}\text { Commission } \\
\text { fees }\end{array}$ & Subsidies & $\begin{array}{l}\text { Overhead } \\
\text { expenses }\end{array}$ & Advertising & $\begin{array}{c}\text { Operational } \\
\text { leasing }\end{array}$ \\
\hline Haven & $\begin{array}{l}0.002^{\star \star *} \\
(0.000)\end{array}$ & $\begin{array}{l}0.001^{\star \star *} \\
(0.000)\end{array}$ & $\begin{array}{l}0.001^{\star \star *} \\
(0.000)\end{array}$ & $\begin{array}{c}0.003^{\star \star \star} \\
(0.000)\end{array}$ & $\begin{array}{l}0.006^{\star \star *} \\
(0.000)\end{array}$ & $\begin{array}{l}0.005^{\star \star \star} \\
(0.000)\end{array}$ & $\begin{array}{l}0.001^{* \star *} \\
(0.000)\end{array}$ & $\begin{array}{l}0.000^{\star \star \star} \\
(0.000)\end{array}$ & $\begin{array}{l}0.004^{\star \star \star} \\
(0.000)\end{array}$ & $\begin{array}{l}0.001^{\star * *} \\
(0.000)\end{array}$ \\
\hline Affilliate & $\begin{array}{l}0.028^{\star \star \star} \\
(0.002)\end{array}$ & $\begin{array}{c}0.011^{\star \star \star} \\
(0.001)\end{array}$ & $\begin{array}{l}0.023^{\star \star \star} \\
(0.003)\end{array}$ & $\begin{array}{c}0.058^{\star \star \star} \\
(0.004)\end{array}$ & $\begin{array}{l}0.130 \star \star \star \\
(0.005)\end{array}$ & $\begin{array}{l}0.034^{\star \star \star} \\
(0.004)\end{array}$ & $\begin{array}{l}0.026^{\star \star \star} \\
(0.003)\end{array}$ & $\begin{array}{l}0.008^{\star \star \star} \\
(0.001)\end{array}$ & $\begin{array}{l}0.046^{\star \star \star} \\
(0.004)\end{array}$ & $\begin{array}{c}0.007^{\star \star \star} \\
(0.001)\end{array}$ \\
\hline Haven $\times$ Affiliate & $\begin{array}{c}0.019^{\star \star *} \\
(0.005)\end{array}$ & $\begin{array}{l}0.019^{\star \star *} \\
(0.004)\end{array}$ & $\begin{array}{c}0.000 \\
(0.004)\end{array}$ & $\begin{array}{l}-0.005 \\
(0.005)\end{array}$ & $\begin{array}{c}0.039^{\star \star *} \\
(0.008)\end{array}$ & $\begin{array}{l}-0.003 \\
(0.005)\end{array}$ & $\begin{array}{l}-0.003 \\
(0.003)\end{array}$ & $\begin{array}{c}0.002 \\
(0.002)\end{array}$ & $\begin{array}{l}0.013^{\star \star} \\
(0.006)\end{array}$ & $\begin{array}{c}0.002 \\
(0.003)\end{array}$ \\
\hline Distance (in logs) & $\begin{array}{l}-0.000 \\
(0.000)\end{array}$ & $\begin{array}{c}-0.000^{* *} \\
(0.000)\end{array}$ & $\begin{array}{c}-0.002^{\star \star *} \\
(0.000)\end{array}$ & $\begin{array}{c}-0.002^{\star \star \star} \\
(0.000)\end{array}$ & $\begin{array}{c}-0.003^{\star \star *} \\
(0.000)\end{array}$ & $\begin{array}{l}-0.000 \\
(0.000)\end{array}$ & $\begin{array}{c}-0.000^{\star \star \star} \\
(0.000)\end{array}$ & $\begin{array}{c}-0.000^{\star * *} \\
(0.000)\end{array}$ & $\begin{array}{c}-0.002^{\star \star *} \\
(0.000)\end{array}$ & $\begin{array}{c}-0.001^{\star * *} \\
(0.000)\end{array}$ \\
\hline GDP (in logs) & $\begin{array}{l}0.001^{* \star *} \\
(0.000)\end{array}$ & $\begin{array}{c}0.000^{* \star *} \\
(0.000)\end{array}$ & $\begin{array}{c}0.001^{\star \star \star} \\
(0.000)\end{array}$ & $\begin{array}{c}0.002^{\star \star \star} \\
(0.000)\end{array}$ & $\begin{array}{c}0.003^{\star \star *} \\
(0.000)\end{array}$ & $\begin{array}{l}0.004^{* \star *} \\
(0.000)\end{array}$ & $\begin{array}{c}0.001^{\star \star *} \\
(0.000)\end{array}$ & $\begin{array}{c}0.000^{\star \star *} \\
(0.000)\end{array}$ & $\begin{array}{c}0.002^{\star \star \star} \\
(0.000)\end{array}$ & $\begin{array}{c}0.000^{\star \star \star} \\
(0.000)\end{array}$ \\
\hline Contiguity & $\begin{array}{c}0.004^{\star \star *} \\
(0.001)\end{array}$ & $\begin{array}{c}0.003^{\star * *} \\
(0.000)\end{array}$ & $\begin{array}{c}0.014^{\star \star \star} \\
(0.001)\end{array}$ & $\begin{array}{c}0.023^{\star \star \star} \\
(0.001)\end{array}$ & $\begin{array}{c}0.026^{\star * *} \\
(0.001)\end{array}$ & $\begin{array}{c}0.017^{\star \star \star} \\
(0.001)\end{array}$ & $\begin{array}{c}0.003^{\star \star \star} \\
(0.001)\end{array}$ & $\begin{array}{l}0.002^{\star \star \star} \\
(0.000)\end{array}$ & $\begin{array}{c}0.014^{* * *} \\
(0.001)\end{array}$ & $\begin{array}{c}0.008^{\star * \star} \\
(0.001)\end{array}$ \\
\hline Common language & $\begin{array}{c}0.007^{\star \star \star} \\
(0.001)\end{array}$ & $\begin{array}{c}0.004^{\star \star \star} \\
(0.001)\end{array}$ & $\begin{array}{l}0.003^{\star \star \star} \\
(0.001)\end{array}$ & $\begin{array}{c}0.014^{\star \star \star} \\
(0.001)\end{array}$ & $\begin{array}{c}0.025^{\star \star \star} \\
(0.001)\end{array}$ & $\begin{array}{l}0.007^{\star \star \star} \\
(0.001)\end{array}$ & $\begin{array}{l}-0.001 \\
(0.001)\end{array}$ & $\begin{array}{l}-0.000 \\
(0.000)\end{array}$ & $\begin{array}{l}0.019^{\star \star \star} \\
(0.001)\end{array}$ & $\begin{array}{c}0.002^{\star \star \star} \\
(0.001)\end{array}$ \\
\hline Observations & $1,501,069$ & $1,385,748$ & $1,574,116$ & $2,369,052$ & $2,603,517$ & $2,308,482$ & $1,475,284$ & $1,294,414$ & $1,934,737$ & $1,481,760$ \\
\hline R-squared & 0.014 & 0.007 & 0.015 & 0.028 & 0.052 & 0.020 & 0.009 & 0.004 & 0.026 & 0.008 \\
\hline Number of firms & 7,859 & 7,371 & 8,114 & 11,613 & 13,083 & 11,659 & 7,724 & 6,922 & 9,821 & 7,840 \\
\hline Parent fixed effects & Yes & Yes & Yes & Yes & Yes & Yes & Yes & Yes & Yes & Yes \\
\hline
\end{tabular}


Table 8: Profitability of foreign affiliates

Business services

Financial servies

Transport services

Construction Information Communication Intellectual

Other

Insurance Financial

Road

Inland water

Haven

$\begin{array}{lll}0.082^{\star \star *} & 0.028 & 0.038\end{array}$

$0.043^{\star \star}$

$0.049 * * *$

0.037

0.026

0.094

$0.074^{\star \star} \quad 0.079^{\star \star \star}$

0.056

$\begin{array}{lllll}(0.030) & (0.017) & (0.031) & (0.019) & (0.011)\end{array}$

$(0.033) \quad(0.021)$

$(0.061)$

$\begin{array}{lll}(0.036) & (0.028) \quad(0.067)\end{array}$

Observations

R-squared

$\begin{array}{lllll}686 & 1,811 & 376 & 1,722 & 5,357\end{array}$

$353 \quad 774$

Number of firm

$\begin{array}{lllll}0.010 & 0.002 & 0.006 & 0.005 & 0.005 \\ 190 & 502 & 148 & 472 & 1,536\end{array}$

Parent-FE

$\begin{array}{lll}196 & 502 & 148 \\ & Y & Y\end{array}$

$472 \quad 1,536$

170

774
0.003

$\begin{array}{llll}263 & 359 & 880 & 173\end{array}$

Average profitability in non-

Aver comparison group

0.133

0.092

0.132

0.117

$0.083 \quad 0.088$

$\begin{array}{lccc}97 & 150 & 337 & 108\end{array}$

mook return on equity defined as gross profits / equity; "Haven" is a dummy coded one if the foreign country is on the tax haven list of Hines (2010); The sample consists of entities in for ing level in parentheses $\left(\star \star \star x p<0.01,{ }^{\star \star} p<0.05,{ }^{\star} p<0.1\right)$. 
Table 9: Conduit trade

\begin{tabular}{|c|c|c|c|c|c|c|c|c|c|c|}
\hline & \multicolumn{3}{|c|}{ Intellectual Property } & \multicolumn{7}{|c|}{$\begin{array}{l}\text { Other business services } \\
\end{array}$} \\
\hline & Patents & Trademarks & $\begin{array}{c}\text { Research \& } \\
\text { Development }\end{array}$ & $\begin{array}{c}\text { Engineering } \\
\text { and technical }\end{array}$ & $\begin{array}{c}\text { Headquarter } \\
\text { services }\end{array}$ & $\begin{array}{c}\text { Commission } \\
\text { fees }\end{array}$ & Subsidies & $\begin{array}{l}\text { Overhead } \\
\text { expenses }\end{array}$ & Advertising & $\begin{array}{c}\text { Operational } \\
\text { leasing }\end{array}$ \\
\hline Haven & $\begin{array}{c}0.002^{\star \star \star} \\
(0.000)\end{array}$ & $\begin{array}{c}0.001^{\star \star \star} \\
(0.000)\end{array}$ & $\begin{array}{c}0.001^{\star \star \star} \\
(0.000)\end{array}$ & $\begin{array}{c}0.003^{\star \star \star} \\
(0.000)\end{array}$ & $\begin{array}{c}0.006^{\star \star *} \\
(0.000)\end{array}$ & $\begin{array}{c}0.005^{\star \star \star} \\
(0.000)\end{array}$ & $\begin{array}{c}0.001^{\star \star \star} \\
(0.000)\end{array}$ & $\begin{array}{c}0.000^{\star \star \star} \\
(0.000)\end{array}$ & $\begin{array}{c}0.004^{\star \star \star} \\
(0.000)\end{array}$ & $\begin{array}{c}0.001^{\star \star \star} \\
(0.000)\end{array}$ \\
\hline Affilliate & $\begin{array}{l}0.026^{\star \star \star} \\
(0.002)\end{array}$ & $\begin{array}{l}0.013^{\star \star \star} \\
(0.001)\end{array}$ & $\begin{array}{c}0.018^{\star \star \star} \\
(0.002)\end{array}$ & $\begin{array}{l}0.057^{\star \star \star} \\
(0.004)\end{array}$ & $\begin{array}{l}0.121^{\star \star \star} \\
(0.004)\end{array}$ & $\begin{array}{l}0.031^{\star \star \star} \\
(0.003)\end{array}$ & $\begin{array}{c}0.018^{\star \star \star} \\
(0.002)\end{array}$ & $\begin{array}{c}0.010^{\star \star \star} \\
(0.001)\end{array}$ & $\begin{array}{l}0.033^{\star \star \star} \\
(0.003)\end{array}$ & $\begin{array}{l}0.006^{\star \star \star} \\
(0.001)\end{array}$ \\
\hline Haven $\times$ Affiliate & $\begin{array}{c}0.025^{\star \star *} \\
(0.006)\end{array}$ & $\begin{array}{c}0.029 * \star \star \\
(0.006)\end{array}$ & $\begin{array}{c}0.007 \\
(0.005)\end{array}$ & $\begin{array}{c}0.001 \\
(0.007)\end{array}$ & $\begin{array}{c}0.058^{\star * *} \\
(0.010)\end{array}$ & $\begin{array}{c}0.006 \\
(0.006)\end{array}$ & $\begin{array}{l}-0.003 \\
(0.004)\end{array}$ & $\begin{array}{c}0.004 \\
(0.004)\end{array}$ & $\begin{array}{c}0.029 * \star \star \\
(0.007)\end{array}$ & $\begin{array}{c}0.002 \\
(0.003)\end{array}$ \\
\hline Haven $\times$ NL Affiliate & $\begin{array}{l}-0.000 \\
(0.000)\end{array}$ & $\begin{array}{l}-0.000 \\
(0.000)\end{array}$ & $\begin{array}{l}0.001^{\star \star \star} \\
(0.000)\end{array}$ & $\begin{array}{l}0.001^{\star *} \\
(0.000)\end{array}$ & $\begin{array}{l}-0.001 \\
(0.001)\end{array}$ & $\begin{array}{c}0.000 \\
(0.001)\end{array}$ & $\begin{array}{l}-0.000 \\
(0.000)\end{array}$ & $\begin{array}{l}0.000^{\star \star} \\
(0.000)\end{array}$ & $\begin{array}{l}-0.000 \\
(0.000)\end{array}$ & $\begin{array}{c}0.000 \\
(0.000)\end{array}$ \\
\hline Affiliate $\times$ NL Affiliate & $\begin{array}{c}0.005 \\
(0.006)\end{array}$ & $\begin{array}{l}-0.006^{\star *} \\
(0.003)\end{array}$ & $\begin{array}{l}0.015^{\star} \\
(0.008)\end{array}$ & $\begin{array}{c}0.004 \\
(0.011)\end{array}$ & $\begin{array}{l}0.028^{\star \star} \\
(0.014)\end{array}$ & $\begin{array}{c}0.009 \\
(0.010)\end{array}$ & $\begin{array}{l}0.022^{* *} \\
(0.009)\end{array}$ & $\begin{array}{c}-0.008^{\star \star \star} \\
(0.001)\end{array}$ & $\begin{array}{l}0.037^{\star \star \star} \\
(0.011)\end{array}$ & $\begin{array}{c}0.003 \\
(0.003)\end{array}$ \\
\hline Haven $\times$ Affiliate $\times \mathrm{NL}$ affiliate & $\begin{array}{l}-0.016^{*} \\
(0.009)\end{array}$ & $\begin{array}{c}-0.025^{\star \star \star} \\
(0.007)\end{array}$ & $\begin{array}{c}-0.019^{\star \star \star} \\
(0.007)\end{array}$ & $\begin{array}{l}-0.016^{\star} \\
(0.010)\end{array}$ & $\begin{array}{c}-0.053^{\star \star \star} \\
(0.015)\end{array}$ & $\begin{array}{c}-0.025^{\star \star \star} \\
(0.010)\end{array}$ & $\begin{array}{l}-0.003 \\
(0.008)\end{array}$ & $\begin{array}{l}-0.003 \\
(0.004)\end{array}$ & $\begin{array}{c}-0.044^{\star \star \star} \\
(0.012)\end{array}$ & $\begin{array}{c}0.001 \\
(0.006)\end{array}$ \\
\hline Observations & $1,500,687$ & $1,385,372$ & $1,573,728$ & $2,368,644$ & $2,603,119$ & $2,308,086$ & $1,474,902$ & $1,294,040$ & $1,934,343$ & $1,481,382$ \\
\hline R-squared & 0.014 & 0.008 & 0.015 & 0.028 & 0.052 & 0.020 & 0.009 & 0.005 & 0.026 & 0.008 \\
\hline Number of firms & 7,857 & 7,369 & 8,112 & 11,611 & 13,081 & 11,657 & 7,722 & 6,920 & 9,819 & 7,838 \\
\hline Parent fixed effects & Yes & Yes & Yes & Yes & Yes & Yes & Yes & Yes & Yes & Yes \\
\hline Covariates & Yes & Yes & Yes & Yes & Yes & Yes & Yes & Yes & Yes & Yes \\
\hline
\end{tabular}


Business services

Construction Information Communication Intellectu

Other

\section{Panel A: Logit model}

Haven

Affilliate

Haven $\times$ Affiliate

Observations

Number of firms

Parent fixed effects

Covariates

\section{Panel B: Country fixed effects}

Haven

Affilliate

Haven $\times$ Affiliate

Observations

R-squared

Number of firms

Parent fixed effects

Country fixed effects

$\begin{array}{cc}1.040 & 5.255^{\star \star \star} \\ (0.0567) & (0.196) \\ 4.524^{\star \star \star} & 6.104^{\star \star \star} \\ (0.375) & (0.310) \\ 1.102 & 0.788^{\star \star} \\ (0.239) & (0.0818) \\ & \\ 367,640 & 865,046 \\ 1,820 & 4,459 \\ \text { Yes } & \text { Yes } \\ \text { Yes } & \text { Yes }\end{array}$

$\begin{array}{ccc}2.845^{\star \star \star} & 2.618^{\star \star \star} & 2.733^{\star \star \star} \\ (0.204) & (0.113) & (0.0455) \\ 3.601^{\star \star \star} & 6.158^{\star \star \star} & 5.165^{\star \star \star} \\ (0.352) & (0.334) & (0.142) \\ 0.934 & 1.631^{\star \star \star} & 1.491^{\star \star \star} \\ (0.176) & (0.193) & (0.104) \\ & & \\ 211,400 & 653,598 & 3,144,495 \\ 1,057 & 3,301 & 15,339 \\ \text { Yes } & \text { Yes } & \text { Yes } \\ \text { Yes } & \text { Yes } & \text { Yes }\end{array}$

Financial servies

Insurance Financial

\begin{tabular}{cccc}
\hline \hline \multicolumn{4}{c}{ Transport services } \\
\hline Air & Sea & Road & Inland water
\end{tabular}

$4.206^{\star \star \star} \quad 5.718^{\star \star \star *}$

(0.307) (0.352)

$14.52^{\star \star \star} \quad 8.093^{\star \star \star}$

$2.833^{\star \star *}$

$\begin{array}{ll}(1.148) & (0.664) \\ 0.350^{* * *} & 0.582^{* * \star}\end{array}$

$(0.161)$
$3.298^{*}$

$5.706^{\star \star \star} 2.175^{\star \star \star} \quad 1.964^{\star \star \star}$

(0.0605) (0.0921)

$\begin{array}{cccc}(0.344) & (0.319) & (0.376) & (0.388) \\ 1.274 & 1.418^{\star} & 1.600^{*} & 1.169\end{array}$

$(0.170)$
$3.040^{*}$

(0.130)

$\begin{array}{llll}(0.286) & (0.263) & (0.441) & (0.293)\end{array}$

$295,740 \quad 295,200$

$\begin{array}{cc}1,590 & 1,476 \\ \text { Yes } & \text { Yes }\end{array}$

$238,200 \quad 677,115 \quad 163,857 \quad 232,218$

$\begin{array}{llll}1,191 & 3,303 & 849 & 1,197\end{array}$

$\begin{array}{llll}\text { Yes } & \text { Yes } & \text { Yes } & \text { Yes } \\ \text { Yes } & \text { Yes } & \text { Yes } & \text { Yes }\end{array}$

Yes Yes

"Haven" is a dummy coded one if the foreign county is on the tax ho list of Hines (2010): "Affiliate" is a dummy coded one if the German firm has a subsidiary or a parent in the foreign country; The regressions include a set of covariates for which coefficients are not reported: "GDP (in logs)" is the log of the Gross Domestic Product of the foreign country; "Distance (in logs) is the log of the geodesic distance between Berlin and the most important city of the foreign country;

"Contiguity" is a dummy coded one if the foreign country shares a border with Germany; "Common language" is a dummy coded one if the foreign country has German as official language. Trade information is from Statistics on International Trade in Service (SITS) provided by the Deutsche Bundesbank (see Biewen et al., 2013); Afflilate information is from Microdatabase Direct Investment (MiDi) provided by the Deutsche Bundesbank (see Lipponer, 2011); GDP is from World 
Figure 1: Tax haven shares in service and goods trade

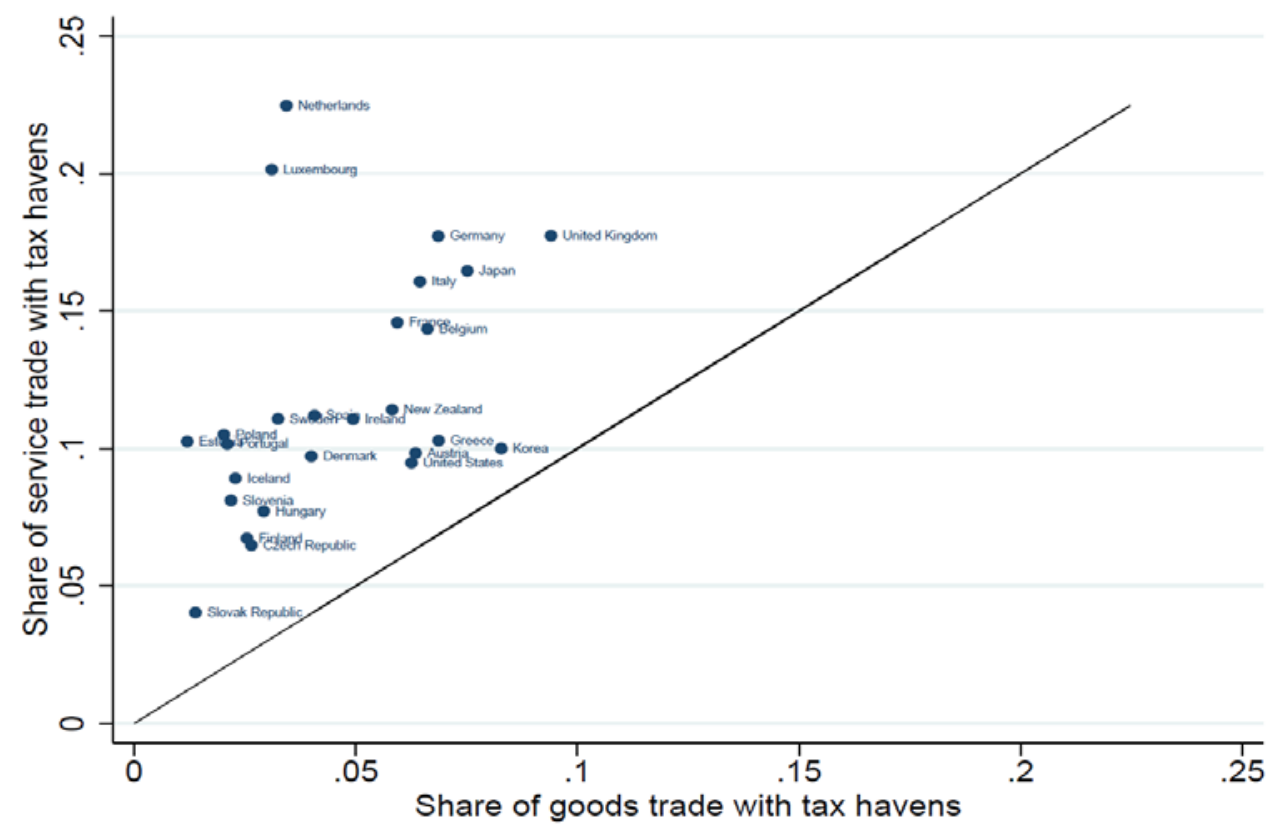

Figure 2: Service imports and profits in tax havens

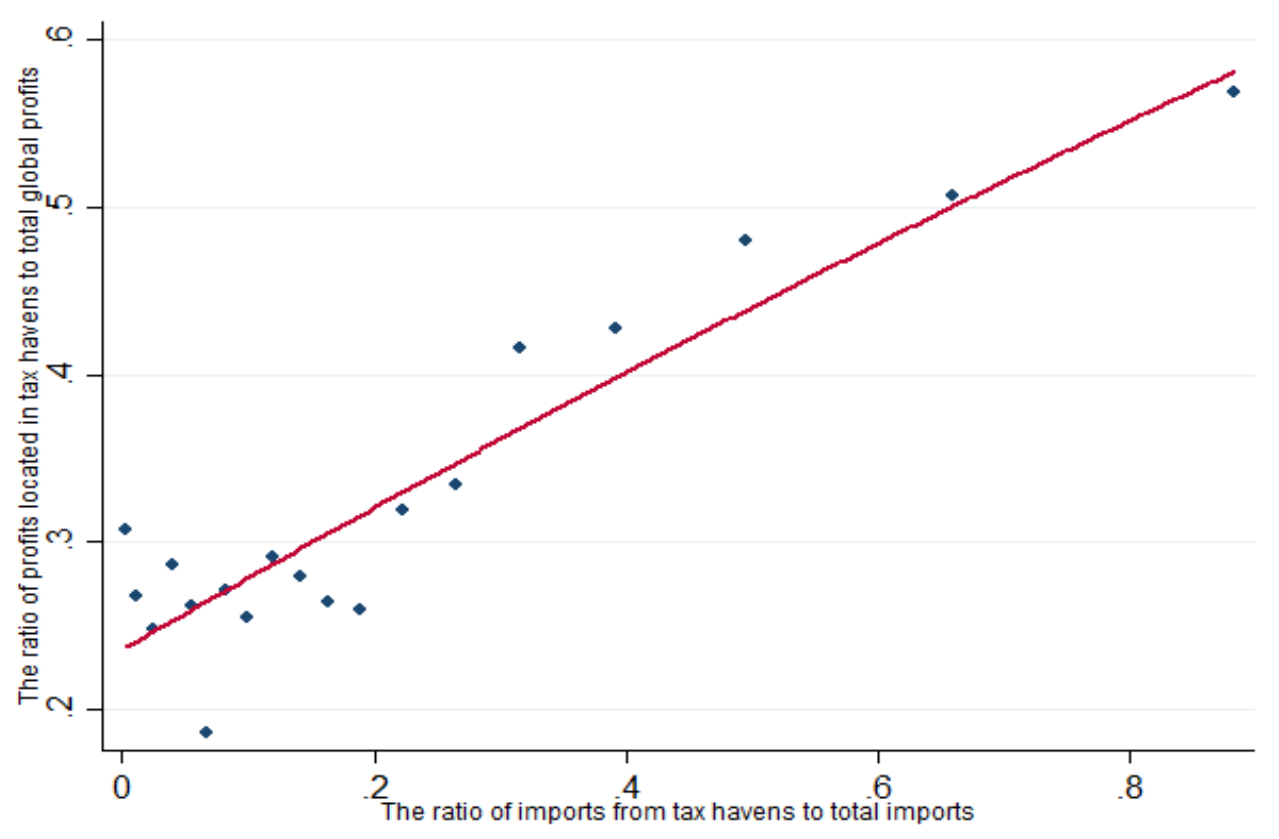

